Review

\title{
Non-Traditional Vectors for Paralytic Shellfish Poisoning
}

\author{
Jonathan R. Deeds ${ }^{1, *}$, Jan H. Landsberg ${ }^{2, *}$, Stacey M. Etheridge ${ }^{1}$, Grant C. Pitcher ${ }^{3}$ and \\ Sara Watt Longan ${ }^{4}$
}

1 US Food and Drug Administration Center for Food Safety and Applied Nutrition, 5100 Paint Branch Parkway, College Park, Maryland, 20723, USA

2 Fish and Wildlife Research Institute, Florida Fish and Wildlife Conservation Commission, 100 Eighth Avenue Southeast, St. Petersburg, Florida, 33712, USA

3 Marine and Coastal Management, Cape Town, South Africa

4 State of Alaska Department of Environmental Conservation, Anchorage, AK, USA

* Authors to whom correspondence should be addressed; Tel.: +1-301-436-1474; Fax: +1-301-4362624; E-mail: jonathan.deeds@fda.hhs.gov (J.R. Deeds); or Tel.: +1-727-896-8626; Fax: +1-727-8230166; E-mail: jan.landsberg@myfwc.com (J.H. Landsberg).

Received: 14 March 2008; in revised form: 3 June 2008 / Accepted: 3 June 2008 / Published: 10 June 2008

\begin{abstract}
Paralytic shellfish poisoning (PSP), due to saxitoxin and related compounds, typically results from the consumption of filter-feeding molluscan shellfish that concentrate toxins from marine dinoflagellates. In addition to these microalgal sources, saxitoxin and related compounds, referred to in this review as STXs, are also produced in freshwater cyanobacteria and have been associated with calcareous red macroalgae. STXs are transferred and bioaccumulate throughout aquatic food webs, and can be vectored to terrestrial biota, including humans. Fisheries closures and human intoxications due to STXs have been documented in several non-traditional (i.e. non-filter-feeding) vectors. These include, but are not limited to, marine gastropods, both carnivorous and grazing, crustacea, and fish that acquire STXs through toxin transfer. Often due to spatial, temporal, or a species disconnection from the primary source of STXs (bloom forming dinoflagellates), monitoring and management of such non-traditional PSP vectors has been challenging. A brief literature review is provided for filter feeding (traditional) and nonfilter feeding (non-traditional) vectors of STXs with specific reference to human effects. We include several case studies pertaining to management actions to prevent PSP, as well as food poisoning incidents from STX(s) accumulation in non-traditional PSP vectors.
\end{abstract}

Keywords: saxitoxins, STXs, paralytic shellfish poisoning, PSP, saxitoxin puffer fish poisoning, SPFP, non traditional vectors, gastropods, crustaceans, puffer fish, public health 


\section{Paralytic Shellfish Toxins and Sources}

Neurotoxic paralytic shellfish toxins, which comprise saxitoxin and saxitoxin related compounds (STXs), are responsible for the sometimes fatal toxic seafood-related syndromes, paralytic shellfish poisoning (PSP) and saxitoxin puffer fish poisoning (SPFP). These compounds are produced by bloom-forming microalgae - mainly marine dinoflagellates -- approximately ten Alexandrium species, Gymnodinium catenatum, and Pyrodinium bahamense -- and freshwater or brackish cyanobacteria, Anabaena circinalis, A. lemmermannii, Aphanizomenon gracile, A. issatschenkoi (as A. flos-aquae), Cylindrospermopsis raciborskii, Lyngbya wollei, Planktothrix sp., and Rivularia sp. STXs comprise saxitoxin and at least 21 derivatives [1] that in various combinations and concentrations have been associated with PSP. No natural toxigenic dinoflagellate or cyanobacteria population has been found to contain all naturally occurring STX derivatives (Table 1). The toxin profile (i.e., the toxin components produced) is considered by some to be characteristic of the microalgal strain or species [2-3], but this finding has not been consistent among all species in all areas. Some of the STX derivatives are highly toxic (as sodium channel-blocking agents in mammals) and include the carbamate toxins, saxitoxin (STX), neosaxitoxin (NEO), and gonyautoxins (GTX1-4). The decarbamoyl analogues (dcSTX, dcNEO, dcGTX1-4) and the deoxydecarbamoyl analogues (doSTX, doGTX2, doGTX3) are of intermediate toxicity. The least toxic derivatives are the $N$-sulfocarbamoyl toxins, B1 (GTX5), B2 (GTX6), and C1-C4 [1, 4]. Although not usually associated with PSP, Cochlodinium polykrikoides (as Cochlodinium type '78) has been shown to produce two unique, zinc-bound, NEO-like compounds [5]. In 1977, Cochlodinium sp. was implicated in PSP outbreaks in Venezuela [6], but corroborative evidence is lacking.

Numerous microalgal species have been documented to produce STXs and all are potentially human health risks via the food chain. However, the sources of the majority of PSP reports are the marine dinoflagellates Alexandrium tamarense, A. fundyense, A. catenella, Gymnodinium catenatum, and Pyrodinium bahamense ${ }^{l}$ [84-85]. Because STXs are also produced by freshwater cyanobacteria, there is a potential for STXs to be transferred through the freshwater food web and pose a risk to human consumers of freshwater products (e.g. mollusks) contaminated by these toxins [86]. STX(s) composition and concentration can vary amongst microalgal species and strains; with geographical location, with environmental factors, and under different experimental conditions [25, 39, 87-88]. Because the toxin profiles of STX-producing dinoflagellate species differ, the exposure dose and the proportion of highly toxic STX derivatives to which animals are exposed will also vary [89-90].

\footnotetext{
${ }^{1}$ Steidinger et al. (1980) [49] distinguished P. bahamense var. compressa from P. bahamense var. bahamense based on morphological, dimensional, and toxicological characteristics. P. bahamense var. compressa was reported to be the toxic variety responsible for Indo-Pacific PSP events while P. bahamense var. bahamense was reported to be non-toxic. Landsberg et al. (2006) [58] reported for the first time STX(s) production from $P$. bahamense in Florida, USA putatively responsible for several cases of SPFP. Badylak et al. (2004) [57] confirmed that the $P$. bahamense variety occurring in Florida waters still conformed to Steidinger et al. (1980) [49] description of $P$. bahamense var. bahamense except that it now appeared to be toxic. The description of $P$. bahamense var. compressa vs. P. bahamense var. bahamense is currently being re-evaluated (K. Steidinger, personal communication), therefore throughout the text $P$. bahamense without varietal designation is used.
} 
Table 1. Microalgal sources of saxitoxins and saxitoxin derivatives (no reference is made to other toxins produced by these species).

\begin{tabular}{|c|c|c|}
\hline Species & Saxitoxin and derivatives & References \\
\hline \multicolumn{3}{|l|}{ Dinoflagellates } \\
\hline Alexandrium acatenella & STX & $7-9$ \\
\hline Alexandrium andersoni & STX, NEO & $10-11$ \\
\hline Alexandrium angustitabulatum & unknown toxin composition & 12 \\
\hline Alexandrium catenella & STX, GTX1-4, NEO,B1-2, C1-4 & $13-21$ \\
\hline Alexandrium cohorticula & STX, GTX1-4 & $22-23$ \\
\hline Alexandrium fundyense & STX, NEO, GTX1-4, C1-2, B1 & $9,24-25$ \\
\hline Alexandrium minutum $(=$ A. lusitanicum $)$ & GTX1-4 & $20,26-30$ \\
\hline Alexandrium ostenfeldii & GTX2-3, B2, C1-2 & $31-34$ \\
\hline Alexandrium tamarense & STX, NEO, GTX1-4, B1, C1, C2, C4 & $9,21,35-40$ \\
\hline Alexandrium tamiyavanichi & STX, GTX1-4, B1, C1-4 & $41-42$ \\
\hline $\begin{array}{l}\text { Cochlodinium polykrikoides }(=C . \\
\text { heterolobatum, Cochlodinium type' } 78)\end{array}$ & zinc-bound carbamoyl hydroxy NEO & 5 \\
\hline Gymnodinium catenatum & STX, NEO, trace GTX2-3, B1-2, C1-4 & $30,41,43-46$ \\
\hline Pyrodinium bahamense & STX, NEO, B1-B2 & $41,47-58$ \\
\hline \multicolumn{3}{|l|}{ Cyanobacteria } \\
\hline Anabaena circinalis & STX, GTX1-4, C1-C2, dcGTX2-3 & $3,59-66$ \\
\hline Anabaena lemmermannii & STX & 67 \\
\hline Aphanizomenon gracile & STX, NEO & 68 \\
\hline $\begin{array}{l}\text { Aphanizomenon issatschenkoi (as A. flos- } \\
\text { aquae) }\end{array}$ & NEO, STX & $69-77$ \\
\hline Cylindrospermopsis raciborskii & STX, NEO, GTX2-3 & $78-79$ \\
\hline Lyngbya wollei & $\begin{array}{l}\text { dcSTX, dcGTX2-3, acetylated STX } \\
\text { analogues }\end{array}$ & $80-81$ \\
\hline Planktothrix sp. & STX & 82 \\
\hline Rivularia sp. & GTX2, GTX4 & 83 \\
\hline
\end{tabular}


STXs are present in a wide range of aquatic organisms and they have been documented to occur when dinoflagellates were apparently absent [91]. Knowledge of the widespread distribution of STXs and results of a series of experimental studies has led to the conclusion that in some cases dinoflagellates are not the only source of STXs [92]. Although still not definitively proven, a bacterial origin for STXs has been proposed, and bacteria may play a role in the production of STXs in certain dinoflagellate species [22, 92-97].

STXs are highly lethal, having an $\mathrm{LD}_{50}$ in mice (intraperitoneally [i.p]) of $10 \mu \mathrm{g} / \mathrm{kg}$ (as compared to an $\mathrm{LD}_{50}$ for sodium cyanide at $10 \mathrm{mg} / \mathrm{kg}$ [27]. STXs are potent neurotoxins that bind to site 1 on the voltage-dependent sodium channel, block the influx of sodium into excitable cells, and restrict signal transmission between neurons. Symptoms of PSP are paresthesia and numbness, first around the lips and mouth and then involving the face and neck; muscular weakness; sensation of lightness and floating; ataxia; motor incoordination; drowsiness; incoherence; progressively decreasing ventilatory efficiency; and in high doses, respiratory paralysis and death [98-99].

\section{Traditional Vectors of Saxitoxins to Human Consumers}

Most humans who experience PSP have consumed toxic bivalves [84], but occasionally, non traditional vectors such as toxic gastropods and crustaceans [85], and rarely toxic fish [52, 100] are implicated (see section 3). Numerous fatal cases of PSP have been reported globally [101] but the successful implementation of programs monitoring for the presence of both STX-producing microalgae and the presence of STXs in shellfish in many countries has helped to minimize public health risks. To our knowledge, all documented human PSP cases have been caused by toxic marine dinoflagellates; for the most part, the geographical distribution of such PSP outbreaks has been related to the global distribution of the various STX-producing species and their toxigenic strains [90].

Because PSP outbreaks typically result from the consumption of toxic marine shellfish, most studies on STXs concern those vector species that are edible, economic resources. Globally, STXs have been documented in numerous species of mollusks, primarily bivalves, and extensive reviews are available on their toxic occurrence, distribution, exposure, biotransformation, and effects [84, 101104]. Only a brief literature survey of STXs in traditional bivalve vectors will be provided here.

STX was first isolated from toxic Washington butterclams, Saxidomus gigantea [105-106]. In the USA, the first red tide bloom that led to a major PSP outbreak occurred in September 1972 from southern Maine to Cape Ann, Massachusetts. Blue mussels (Mytilus edulis) and softshell clams (Mya arenaria) were most susceptible to STX(s) accumulation and were the most toxic bivalves. Northern quahogs (Mercenaria mercenaria) did not accumulate toxins, even in areas where blue mussels and softshell clams had high STX(s) levels. Eastern oysters (Crassostrea virginica) had very low STX levels [107]. In a few isolated areas, softshell clams and blue mussels remained toxic until April 1973 [108], but it is not known whether this was due to slow depuration or a re-occurrence of toxic cells.

The fate and distribution of STXs in bivalves varies according to harmful algal bloom (HAB) characteristics; environmental conditions; prior history of exposure; species, intrapopulation, and individual variability; uptake dynamics and detoxification mechanisms; anatomical localization and retention; physiological breakdown or biotransformation mechanisms; and differences in initial toxicity of dinoflagellates [84, 101, 103-104, 109-115]. Differences between bivalve species in the 
ability to accumulate STXs have been correlated with each species' in vitro nerve sensitivity to STX and ability to continue actively feeding during toxic blooms [116-117]. Some bivalves demonstrate resistance to STXs [118] contributing to an increased risk of PSP in humans [119].

Bivalves retain STXs for different lengths of time, and the toxic components retained vary; knowledge about these differences aids in the management and prevention of PSP. Some species depurate toxins rapidly whereas others are slow to depurate. A range of STX toxicity levels is found in different bivalve species. Extremely high STX concentrations have been found in the mussels Mytilus trossulus and M. edulis, in softshell clams and Washington butterclams, and in the scallops Patinopecten yessoensis and Placopecten magellanicus. In other bivalves, such as northern quahogs and oysters, Crassostrea spp., STXs are at low levels or are absent [84, 89, 104]. Depuration times also vary between species. Most species can eliminate STXs within weeks [84, 101], whereas Washington butterclams, sea scallops (P. magellanicus), and Atlantic surfclams (Spisula solidissima), are known to retain high levels of toxins for long periods of time (from months to more than five years) $[102,109,120]$.

The toxin profiles of toxic bivalves and associated PSP risks to human consumers vary depending upon the toxigenicity of the dinoflagellate species to which the mollusks are exposed. For example, in general, bivalves exposed to Alexandrium tamarense, A. catenella, and A. minutum accumulate high GTX levels, whereas bivalves exposed to Pyrodinium bahamense and G. catenatum accumulate very low levels of GTX [89]. Bivalve toxin profiles also vary by geographic region, by season, and by the distribution of toxic components in different tissues [2, 102, 109-110, 120-122]. The location and deposition weight of toxin components in the various bivalve organs vary between species. For example, in the scallops $P$. magellanicus and P. yessoensis, the majority of the toxins are concentrated in the digestive gland, and while toxicity levels in the gills, gonads, and adductor muscles are typically less than the regulatory action level of $80 \mu \mathrm{g}$ STXeq/100g, concentrations in gills and gonads have on occasion been above regulatory limits [123]. Since toxins are not readily accumulated in the adductor muscle of scallops, when this is the only part of the shellfish consumed, they are usually considered safe for public consumption, even in the presence of toxic algae [102].

Because they naturally ingest a variety of dinoflagellate species and strains, bivalves are exposed to a variety of toxic components. Knowledge of which toxins are deposited in which tissues and how they are biotransformed at each trophic level may be critical for determining the public health risk associated with the consumption of different shellfish species and their consumable tissues. For example, Atlantic surfclams and sea scallops are naturally exposed in New England to STXs associated with Alexandrium spp. STXs are typically stored in the tissues of these species, whereas other potentially poisonous substances such as the carbamate-derivative gonyautoxins are converted to less toxic compounds. The ability to convert carbamate toxins to their corresponding nontoxic decarbamoyl derivatives has been demonstrated in a few bivalves, such as Atlantic surfclams; Pacific littleneck clams, Protothaca staminea; and the Japanese clams Peronidia venulosa and Mactra chinensis [1, 110, 117, 124]. Because of public health concerns and the development of safety protocols, it is critical that we understand the dynamics of toxin distribution in different species, particularly in edible tissues. 


\section{Non-Traditional Vectors of Saxitoxins to Human Consumers}

Non-bivalve invertebrates, the primary focus of this review, have increasingly been documented to accumulate STXs [85] and have been implicated in PSP incidents. Amongst the mollusks, apart from traditional bivalve vectors, gastropods (Table 2) and rarely cephalopods (the octopus Abdopus sp. [125]), accumulate STXs apparently without any obvious ill effects [126, 127].

\subsection{Gastropods}

Molluscan gastropods including oysterdrills, volutes, whelks, periwinkles, moon snails, conch, slipper limpets, and turban shells (Table 2) accumulate STXs primarily acquired through predation (in many cases of toxic bivalves) [85, 128].

Because gastropods are able to bioaccumulate high concentrations of STXs, they are a significant risk to human consumers, and have been the cause of multiple fatalities, particularly in the Far East (Table 2). In gastropods, STXs are typically concentrated in the digestive gland but some species such as the moon snail, Lunatia heros, concentrate toxin in the muscle tissue [85]. Variability in toxicity is also a function of species differences in predatory habits, differential acquisition of toxins by individuals, sporadic feeding, their ability to move away from toxin sources, and because gastropods are slow to depurate toxins [85].

\subsubsection{Case Study 1: STXs in Abalone}

Unlike filter-feeding bivalve mollusks, gastropods such as abalone (other common names: ormer and perlemon) feed by scavenging, predation, and grazing. Their diet primarily consists of kelp and other seaweeds, making them unlikely candidates for PSP. However, there have been reports of PSP toxins in abalone off the northwest coast of Spain [83, 148-149] and the west and south coasts of South Africa [150].

$\underline{\text { Spain }}$ - STXs were first detected in the Galician abalone Haliotis tuberculata in 1991. Subsequently, abalone in this region was affected by toxin concentrations sufficiently high enough to enforce indefinite closure of the industry in 1993 [148]. dcSTX was the most abundant toxin reported in abalone, followed by low concentrations of STX [83, 148-149]. The source of these toxins remains unknown. The dinoflagellates Gymnodinium catenatum and Alexandrium minutum are the common STX(s) producers in this region; however, they do not display temporal or geographical distributions corresponding to that of abalone toxicity [83, 151]. Also, the toxin profile of these potential sources differs from that of the abalone; although biotransformation may be responsible for this discrepancy. The authors postulated that cyanobacteria may be the source of the toxin and they report measurable $\operatorname{STX}(\mathrm{s})$ concentrations for the cyanobacterium Rivularia sp. It is noteworthy that no other PSP problems were reported for other mollusks or crustaceans in this region [149]. Anatomical distribution showed high toxicity in the epipodial fringe $[149,151]$ with as much as 2.6 times more toxin in the epithelium compared to the foot. Toxicity generally increased with increasing abalone size. Depuration of toxin in abalone did not occur during three months of monitoring cultured abalone fed a variety of macroalgae [83]. No other abalone PSP reports have been reported for this area in the recent literature. However, there was a report by Huchette and Clavier (2004) [152] that indicated the abalone fishery reopened in Spain in 2002, but was closed again shortly thereafter due to an oil spill. 
Table 2. Maximum STX concentrations, microalgal sources, and global PSP reports in gastropods.

\begin{tabular}{|c|c|c|c|c|c|}
\hline $\begin{array}{c}\text { Gastropod species and } \\
\text { presumptive microalgal } \\
\text { source } \\
\end{array}$ & Common name & Maximum STX(s) concentration & Incident & Location & Reference \\
\hline \multicolumn{6}{|l|}{ Alexandrium acatenella } \\
\hline Polinices lewisii & Lewis moon snail & 176-600 $\mu \mathrm{g}$ STX eq. $/ 100 \mathrm{~g}$ tissue & & British Columbia, Canada & 129 \\
\hline \multicolumn{6}{|l|}{ Alexandrium catenella } \\
\hline Adelomelon ancilla & Volute & toxic & & Chile & 85 \\
\hline Argobuccinum sp. & Whelk & $\begin{array}{l}\text { Stomach } 5629 \mu \mathrm{g} \text { STX eq. } / 100 \mathrm{~g} \\
\text { tissue; Muscle } 92 \mu \mathrm{g} \text { STX eq. } / 100 \mathrm{~g} \\
\text { tissue }\end{array}$ & & & \\
\hline Concholepas concholepas & Barnacle rock shell & toxic & & & \\
\hline Trophon sp. & Trophon & toxic & & & \\
\hline Nassarius $\mathrm{sp}$ & $\begin{array}{l}\text { Nassa mud snail (dog } \\
\text { whelk) }\end{array}$ & $9 \mu \mathrm{g}$ STX eq. $/ 100 \mathrm{~g}$ tissue & & Washington, USA & 85 \\
\hline Neptunea spp. & & $\begin{array}{l}200-250 \mathrm{MU}^{*} 100 \mathrm{~g}^{-1} \text { whole } \\
\text { individuals }\end{array}$ & & Alaska, USA & 85 \\
\hline Thais sp. & Oyster drill & $\begin{array}{l}23 \mu \mathrm{g} \text { STX eq. } / 100 \mathrm{~g} \text { tissue (GTX } 2 \\
\text { and GTX } 3 \text { only) }\end{array}$ & & Washington, USA & 85 \\
\hline Thais lamellosa & Oyster drill & Whole animal positive & & & \\
\hline Thais lima & Oyster drill & $\begin{array}{l}\text { Whole animal } 180 \mu \mathrm{g} \text { STX eq. } / 100 \mathrm{~g} \\
\text { tissue }\end{array}$ & & & \\
\hline \multicolumn{6}{|l|}{ Alexandrium tamarense } \\
\hline Littorina sitkana & Sitka periwinkle & Trace whole animal & & Washington, USA & 85 \\
\hline $\begin{array}{l}\text { Lunatia heros (as Polinicies } \\
\text { heros) }\end{array}$ & Northern moon snail & $1450 \mu \mathrm{g}$ STX eq. $/ 100 \mathrm{~g}$ tissue & 2 cases PSP & Massachusetts, USA & 130 \\
\hline Buccinum undatum & Waved whelk & whole body $608 \mu \mathrm{g}$ STX eq. $/ 100 \mathrm{~g}$ & 12 cases PSP, 4 & Quebec, Canada & 85,131 \\
\hline
\end{tabular}




\begin{tabular}{|c|c|c|c|c|c|}
\hline & & tissue; digestive gland $1600 \mu \mathrm{g} \mathrm{STX}$ & fatalities & & \\
\hline & & $3337 \mu \mathrm{g}$ STX eq. $/ 100 \mathrm{~g}$ tissue & $\begin{array}{l}\text { Illnesses and } \\
\text { deaths }\end{array}$ & Gulf of Maine, USA & 85,132 \\
\hline Crepidula fornicata & Slipper limpet & $46-58 \mu \mathrm{g}$ STX eq. $/ 100 \mathrm{~g}$ tissue & & & \\
\hline Colus stimpsoni & Stimpson's colus & toxic & & & \\
\hline $\begin{array}{l}\text { Lunatia heros (=Euspira } \\
\text { heros, Polinices heros) }\end{array}$ & Northern moon snail & $2922 \mu \mathrm{g}$ STX eq. $/ 100 \mathrm{~g}$ tissue & & & \\
\hline Neptunea decemcostata & Ten-ridged whelk & $\begin{array}{l}\text { Raw } \sim 3000-4000, \text { steamed } 1060 \mu \mathrm{g} \\
\text { STX eq. } / 100 \mathrm{~g} \text { tissue }\end{array}$ & & & \\
\hline Thais lapillus & Purpura & $34 \mu \mathrm{g}$ STX eq. $/ 100 \mathrm{~g}$ tissue & & & \\
\hline $\begin{array}{l}\text { Lunatia heros (=Euspira } \\
\text { heros, Polinices heros) }\end{array}$ & Northern moon snail & $247 \mu \mathrm{g}$ STX eq. $/ 100 \mathrm{~g}$ tissue & & $\begin{array}{l}\text { Gulf of St. Lawrence, } \\
\text { Canada }\end{array}$ & 133 \\
\hline Adelomedon brasiliana & Volute & $28 \mathrm{MU} \mathrm{g}^{-1}$ whole & & Argentina & 134 \\
\hline Zidona angulata* & Volute & $\begin{array}{l}210 \mathrm{MU} \mathrm{g}^{-1} \text { viscera; } 25 \mathrm{MU} \mathrm{g}^{-1} \text { foot; } \\
17 \mathrm{MU} \mathrm{g}^{-1} \text { mucus }\end{array}$ & Mild case of PSP & & \\
\hline Busycon spp. & Whelk & $50-500 \mathrm{MU} 100 \mathrm{~g}^{-1}$ & & Quebec, Canada & 85 \\
\hline Rapana venosa & Veined rapa whelk & 11.4 $\mathrm{MU} \mathrm{g}^{-1}$ viscera & & Hiroshima Bay, Japan & 135 \\
\hline \multicolumn{6}{|l|}{ Gymnodinium catenatum } \\
\hline Haliotis tuberculata & Abalone & $467 \mu \mathrm{g}$ STX eq. $/ 100 \mathrm{~g}$ muscle & & Spain & 83 \\
\hline \multicolumn{6}{|l|}{ Pyrodinium bahamense } \\
\hline Lambis lambis & Spider conch & ND - $175 \mathrm{MU} 100 \mathrm{~g}^{-1}$ whole & Several PSP cases & Sabah, Malaysia & $136-137$ \\
\hline Oliva vidua fulminans & Olive & $2525{\mathrm{MU} 100 \mathrm{~g}^{-1} \text { whole }}$ & $\begin{array}{l}5 \text { human fatalities; } \\
8 \text { cases of PSP }\end{array}$ & Malaysia & $136-138$ \\
\hline Natica sp.** & "Tekuyong" & $71-876 \mathrm{MU} 100 \mathrm{~g}^{-1}$ & & Borneo & $139-140$ \\
\hline
\end{tabular}




\begin{tabular}{|c|c|c|c|c|c|}
\hline \multicolumn{6}{|l|}{ Unknown origin } \\
\hline Nassarius siguijorensis & Nassa & $370 \mathrm{MU} 100 \mathrm{~g}^{-1}$ & & $\begin{array}{l}\text { Daya Bay, Guangdong } \\
\text { Province }\end{array}$ & 141 \\
\hline Nassarius succinctus & Nassa & & $\begin{array}{l}68 \text { cases of PSP, } \\
\text { March-Aug 1979; } \\
1 \text { fatality and } 7 \\
\text { hospitalized }\end{array}$ & Zhejiang Povince, China & 128,142 \\
\hline \multirow[t]{2}{*}{ Nassarius spp. } & Nassa & & $\begin{array}{l}50 \text { PSP cases, } 3 \\
\text { fatalities, April- } \\
\text { May } 2002\end{array}$ & Fujian Province, China & 128 \\
\hline & & & $\begin{array}{l}55 \text { PSP cases, } 1 \\
\text { fatality; summer } \\
2004\end{array}$ & Yin Chuan city, China & 128 \\
\hline Nassarius spp. & Nassa & $107,413 \mathrm{MU} 100 \mathrm{~g}^{-1}$ & & Zhoushan Islands, China & 128 \\
\hline Charonia lampas & Trumpet shell & 17.5 $\mathrm{MU} \mathrm{g}^{-1}$ digestive gland & & Galicia, Spain & 143 \\
\hline Natica lineata & Lined moon shell & PSP toxins & & Taiwan & 144 \\
\hline Natica vitellus & Calf moon shell & & & & \\
\hline Niotha clathrata & Basket shell & PSP, GTX-3 & & & $144-145$ \\
\hline Neptunea arthritica & Arthritic neptune & GTX 1-4, neoSTX, STX & & Sanriku coast, Japan & 146 \\
\hline Tectus fenestratus & Fenestrate top shell & $18.7 \mu \mathrm{g}$ STX eq. $/ 100 \mathrm{~g}$ tissue & & Northwest Australia & 147 \\
\hline Tectus nilotica maxima & Top shell & $5.0 \mathrm{MU} \mathrm{g}^{-1}$ whole & & Ishigaki Island, Japan & 52 \\
\hline Tectus pyramis & Top shell & $19 \mathrm{MU} \mathrm{g}^{-1}$ whole & & Ishigaki Island, Japan & 52 \\
\hline Turbo argyrostoma & Turban shell & $20 \mathrm{MU} \mathrm{g}^{-1}$ whole & & Ishigaki Island, Japan & 52 \\
\hline Turbo marmorata & Turban shell & 4.2 $\mathrm{MU} \mathrm{g}^{-1}$ whole & & Ishigaki Island, Japan & 52 \\
\hline
\end{tabular}

$* \mathrm{MU}=$ mouse units $(1 \mathrm{MU}=0.18 \mu \mathrm{gSTX})$

** Presumed, genus and species name not given by author. 
South Africa - Abalone harvesting represents an old fishery in South Africa and currently this fishery includes recreational, subsistence and commercial harvesting. In addition to wild harvest, the 1990's represented a period of movement towards land-based abalone farms. In 1999, STXs were detected in abalone from two farms located along the west coast of South Africa [150]. Subsequent testing also found the presence of toxins in wild abalone. Throughout this evaluation of abalone PSP, toxicity was tested using the AOAC mouse bioassay with levels reported from below the limit of detection to greater than $1600 \mu \mathrm{g}$ STX eq/100 g. For most of these cases, analysis was conducted on the entire animal; however, some samples were separated into specific body parts to examine anatomical distribution. As with other organisms, there appears to be large variability in toxicity between individuals (5-10 fold variability reported). Observations of detached and paralyzed abalone in the wild were made and analysis confirmed the presence of STXs. Pitcher et al. [150] found a geographical gradient in toxicity with the highest toxicity observed in abalone from the north and a general decrease southwards. The notable distinction in toxin composition for South African abalone compared to those from Spain is that only STX was detected in the former [150]. This profile is different from the known STX(s) source (Alexandrium catenella) and other vectors (e.g. mussels Mytilus galloprovincialis) in the area [150, 153]. Given the toxin profile differences and the feeding behavior of abalone, it is uncertain what the source of STXs is to the abalone. Further investigations by Etheridge et al. [154] indicated the putative source of toxins to be from their natural diet, the macroalgal kelp Eklonia mamixa. Depuration studies suggest that either abalone can retain the toxins for long periods of time or the toxin was still present during the studies. Pitcher et al. (2001) [150] found that abalone retained toxins for at least seven months with no apparent decline in toxicity when kept under controlled laboratory experiments with kelp as the diet. Controlled feeding experiments [154] were conducted using juvenile abalone ( $2 \mathrm{~cm}$ in length, average wet weight $0.6 \pm 0.3 \mathrm{~g}$ ) and demonstrated that depuration did not occur when abalone were either fed kelp or were starved. However, depuration rates of $6.3 \mu \mathrm{g}$ per $100 \mathrm{~g}$ per day were observed when abalone was fed artificial feed. Initial toxicity in the abalone was $160 \pm 38 \mu \mathrm{g}$ STX eq per $100 \mathrm{~g}$ and after being fed artificial feed for two weeks toxin levels decreased to $72.3 \pm 12.5 \mu \mathrm{g}$ STX eq per 100. Thus, it is possible that feeding farmed abalone artificial feed prior to market could reduce the risk of PSP. Toxin distribution among abalone tissues demonstrates differential uptake and compartmentalization. Thus, the contribution of each tissue to total toxin burden is a function of both its absolute toxicity and relative weight contribution. Pitcher et al. [150] found moderate amounts in the foot and viscera and high amounts in the epipodial fringe. Given the high surface area of the epipodial fringe, it contributes significantly to the total toxin burden. Abalone is often marketed with the foot for human consumption; therefore, it has been suggested that scrubbing and/or removing epithelial tissue could decrease toxicity to safe levels for consumption. This could potentially be used as a strategy to reduce toxin levels prior to market.

Periodic PSP events still occur along the west coast of South Africa. In many cases this has resulted in prevention of exporting live abalone. However, shucking and scrubbing (i.e. removing the epithelial layer of the abalone) decreased toxicity to safe levels (aggregate toxicity $<80 \mu \mathrm{g} / 100 \mathrm{~g}$ whole animal). For example, Pitcher et al. [150] found that toxicity levels in the foot and epipodial fringe (one of the largest reservoirs of STXs containing $>800 \mu \mathrm{g} / 100 \mathrm{~g}$ in some cases) both decreased significantly (approximately 6 to 9 -fold) when scrubbed. Currently, testing for toxins is done regularly under the 
South African Shellfish Sanitation Program run by Marine and Coastal Management under an MOU. When traces of toxin are detected, sampling frequency increases and farms in the affected area can be prevented from exporting. Again, shucking, scrubbing and cleaning remain processing options (e.g. canning) that can be used to safely market abalone from this region.

\subsubsection{Case Study 2: STXs in Whelks and Moon Snails}

Japan - During surveillance on the toxicity of invertebrates such as bivalves inhabiting the coasts of Hiroshima Bay in 2001 and 2002, the carnivorous gastropod rapa whelk Rapana venosa, collected in the estuary of Nikoh River, was found to contain toxins which showed paralytic actions in mice; the maximum toxicities (as STXs) were 4.2 MU/g (May 2001) and 11.4 MU/g (April 2002). This equated to total toxicities of 224 and $206 \mathrm{MU} /$ viscera for these specimens ( $1 \mathrm{MU}=0.18 \mu \mathrm{gSTX}$ ). In an attempt to identify the toxic principle(s) in this gastropod, the viscera were extracted with $80 \%$ ethanol acidified with acetic acid, followed by defatting with dichloromethane. The aqueous layer obtained was treated with activated charcoal and then applied to a Sep-Pak C18 cartridge. The unbound toxic fraction was analyzed by high-performance liquid chromatography. The gastropod toxin was rather unexpectedly identified as STXs. It was comprised of GTX3, GTX2, and STX as the major components, which accounted for approximately $91 \mathrm{~mol} \%$ of all components along with STXs $\mathrm{Cl}$ and $\mathrm{C} 2$, which are $\mathrm{N}$-sulfocarbamoyl derivatives. Judging from their toxin patterns, it was suggested that the STX(s) toxification mechanism of the gastropod was phytoplankton, such as Alexandrium tamarense, transferred to and accumulated in filter-feeders such as the short-necked clam, and then transferred to this carnivorous whelk through predation [137].

New England, USA - Several species of moon snail and whelk are also known to accumulate STXs and such gastropods are often prohibited for harvesting in waters of the states of Maine and Massachusetts, USA. Closures in waters off the coast of Maine are made by the Department of Marine Resources and are posted on their website (http://www.maine.gov/dmr/rm/public_health/closures/pspclosures.htm [accessed 3 March, 2008]). The moon snail of interest in this area is Lunatia heros, and the whelks impacted by closures are of the family Muricidae and Buccinidae. In Maine state waters, harvesting of moon snails and the whelk Buccinum undatum is closed as a precaution whenever the blue mussel Mytilus edulis exceeds the regulatory limit for STXs, due to the observation that if there are any bivalves carrying STXs then any co-occurring carnivorous gastropods will be toxic as well (D. Couture, pers. comm.). The Division of Marine Fisheries is responsible for the safety of seafood harvested in Massachusetts state waters and their closures can be found on their website (http://www.mass.gov/dfwele/dmf [accessed 3 March, 2008]). Off the coast of Massachusetts, closures are often in effect for the lobed moon snail Polinices duplicatus and the northern moon snail L. heros, as well as the channeled whelk Busycon canaliculatum and the knobbed whelk B. carica (M. Hickey, pers. comm.). Notably, harvesting closures are often extended for moon snails longer than for other species because they accumulate higher levels of toxin by feeding on toxic bivalves. Certain carnivorous mollusks also appear to retain toxins for longer periods of time than the source bivalves. For example, an extensive Alexandrium fundyense bloom occurred off the coast of New England in 2005 resulting in PSP closures of vast regions in state and federal waters [155]. The U.S. Food and Drug Administration is responsible for the safety of seafood harvested in federal waters and they 
began sampling shellfish in the impacted areas during the 2005 bloom. Sampling continued in 2006 and toxicity levels above the action level were still being detected for moon snails and whelk from federal waters off the coast of Massachusetts (Table 3). In that region, the only other species that remained toxic was the sea scallop (P. magellanicus), in the viscera (Table 3). Sea scallops are known to retain toxins in viscera for long periods of time compared to other co-occurring species [104]. These data demonstrate the need to monitor toxicity for these non-traditional seafood products, even after bloom conditions have dissipated.

Table 3. Shellfish collected from New England, USA, federal waters in 2006. All testing was done by $\mathrm{H}^{3} \mathrm{STX}$ receptor binding assay. Highlighted results indicate individuals above the action level ( $80 \mu \mathrm{g}$ STX eq./100g tissue). $\mathrm{M}=$ male, $\mathrm{F}=$ female; LOD = below detection limit.

\begin{tabular}{|c|c|c|c|c|c|}
\hline $\begin{array}{c}\text { Sampling } \\
\text { Date } \\
\end{array}$ & $\begin{array}{c}\text { Common } \\
\text { Name } \\
\end{array}$ & Scientific Name & $\begin{array}{c}\text { Number of } \\
\text { Animals }\end{array}$ & $\begin{array}{c}\text { Sampling } \\
\text { Coordinates }\end{array}$ & $\begin{array}{c}\text { STX eq. } \\
(\mu \mathrm{g} / 100 \mathrm{~g})\end{array}$ \\
\hline $7-8-06$ & Ocean Quahog & Arctica islandica & 8 & $\begin{array}{l}4100.183 \mathrm{~N} \\
7044.543 \mathrm{~W}\end{array}$ & 7.2 \\
\hline $7-8-06$ & Ocean Quahog & Arctica islandica & 3 & $\begin{array}{l}4106.476 \mathrm{~N} \\
7027.150 \mathrm{~W}\end{array}$ & 11.6 \\
\hline 7-9-06 & Whelk & Busycon sp. & 3 & $\begin{array}{l}4125.057 \mathrm{~N} \\
7002.751 \mathrm{~W}\end{array}$ & 234.3 \\
\hline 7-9-06 & $\begin{array}{l}\text { Atlantic } \\
\text { Surfclam }\end{array}$ & $\begin{array}{c}\text { Spisula } \\
\text { solidissima }\end{array}$ & 3 & $\begin{array}{l}4125.057 \mathrm{~N} \\
7002.751 \mathrm{~W}\end{array}$ & 15.6 \\
\hline $7-9-06$ & Blue Mussels & Mytilus edulus & 12 & $\begin{array}{l}4123.836 \mathrm{~N} \\
6953.954 \mathrm{~W}\end{array}$ & 19.5 \\
\hline $7-9-06$ & Blue Mussels & Mytilus edulus & 12 & $\begin{array}{l}4123.836 \mathrm{~N} \\
6953.954 \mathrm{~W}\end{array}$ & 26.3 \\
\hline 7-9-06 & $\begin{array}{l}\text { Northern } \\
\text { Moon Snail }\end{array}$ & Lunatia heros & 3 & $\begin{array}{l}4126.084 \mathrm{~N} \\
7003.000 \mathrm{~W}\end{array}$ & 265.5 \\
\hline 7-9-06 & $\begin{array}{c}\text { Northern } \\
\text { Moon Snail }\end{array}$ & Lunatia heros & 7 & $\begin{array}{l}4123.836 \mathrm{~N} \\
6953.954 \mathrm{~W}\end{array}$ & 321.0 \\
\hline $7-10-06$ & Sea Scallops & $\begin{array}{l}\text { Placopecten } \\
\text { magellanicus }\end{array}$ & 9 & $\begin{array}{l}4209.865 \mathrm{~N} \\
7018.279 \mathrm{~W}\end{array}$ & 228.8 \\
\hline $7-10-06$ & $\begin{array}{l}\text { Sea Scallop } \\
\text { viscera }(F)\end{array}$ & $\begin{array}{l}\text { Placopecten } \\
\text { magellanicus }\end{array}$ & 1 & $\begin{array}{l}4209.865 \mathrm{~N} \\
7018.279 \mathrm{~W}\end{array}$ & 93.6 \\
\hline $7-10-06$ & $\begin{array}{l}\text { Sea Scallop } \\
\text { viscera }(\mathrm{M})\end{array}$ & $\begin{array}{l}\text { Placopecten } \\
\text { magellanicus }\end{array}$ & 1 & $\begin{array}{l}4209.865 \mathrm{~N} \\
7018.279 \mathrm{~W}\end{array}$ & 131.9 \\
\hline $7-11-06$ & Ocean Quahog & Arctica islandica & 11 & $\begin{array}{l}4212.025 \mathrm{~N} \\
7022.017 \mathrm{~W}\end{array}$ & $<\mathrm{LOD}$ \\
\hline $7-11-06$ & Sea Scallop & $\begin{array}{l}\text { Placopecten } \\
\text { magellanicus }\end{array}$ & 6 & $\begin{array}{l}4211.391 \mathrm{~N} \\
7019.700 \mathrm{~W}\end{array}$ & 50.6 \\
\hline $7-11-06$ & $\begin{array}{c}\text { Northern } \\
\text { Moon Snails }\end{array}$ & Lunatia heros & 6 & $\begin{array}{l}4211.391 \mathrm{~N} \\
7019.700 \mathrm{~W}\end{array}$ & 318.9 \\
\hline
\end{tabular}




\begin{tabular}{|c|c|c|c|c|c|}
\hline $7-11-06$ & $\begin{array}{c}\text { Ocean } \\
\text { Quahogs }\end{array}$ & Arctica islandica & 12 & $\begin{array}{l}4212.025 \mathrm{~N} \\
7022.017 \mathrm{~W}\end{array}$ & $<\mathrm{LOD}$ \\
\hline $7-11-06$ & Blue Mussels & Mytilus edulus & 9 & $\begin{array}{l}4212.025 \mathrm{~N} \\
7022.017 \mathrm{~W}\end{array}$ & 5.0 \\
\hline $7-11-06$ & $\begin{array}{l}\text { Atlantic } \\
\text { Surfclam }\end{array}$ & $\begin{array}{c}\text { Spisula } \\
\text { solidissima }\end{array}$ & 2 & $\begin{array}{l}4211.391 \mathrm{~N} \\
7019.700 \mathrm{~W}\end{array}$ & 16.1 \\
\hline $7-11-06$ & Ocean Quahog & Arctica islandica & 5 & $\begin{array}{l}4212.025 \mathrm{~N} \\
7022.017 \mathrm{~W}\end{array}$ & 12.0 \\
\hline $7-11-06$ & Ocean Quahog & Arctica islandica & 4 & $\begin{array}{l}4211.391 \mathrm{~N} \\
7019.700 \mathrm{~W}\end{array}$ & 0.2 \\
\hline
\end{tabular}

* Number of whole animals homogenized to form representative sample.

** For sea scallops only combined viscera and gonad tested, unless otherwise indicated.

\subsection{Crustaceans}

Among non-filter feeding, non-molluscan species, STXs have been found most commonly in xanthid crabs (Table 4) [156-159]. In some cases, toxins were believed to be derived from the calcareous alga Jania sp., consumed by the crabs [160]. STXs have also been found in other crab species, lobsters, crayfish, penaeid shrimp, barnacles (Table 4) and a few other crustacea [85, 147].

Many macrocrustaceans, including lobsters, are able to tolerate and hence concentrate extremely high levels of STXs. Lobsters can accumulate STXs by preying on, among other species, blue mussels which can have maximum toxicities of up to 23,000 $\mu \mathrm{g} \mathrm{STX} \mathrm{eq/100g} \mathrm{[162].} \mathrm{Jiang} \mathrm{et} \mathrm{al.} \mathrm{(2006)} \mathrm{[175]}$ demonstrated the transfer and metabolism of STXs from the scallop Chlamys nobilis to spiny lobsters Panulirus stimpsoni. When experimentally fed with toxic viscera of $C$. nobilis, the hepatopancreas of P. stimpsoni showed the same toxin profile as that of the scallop, including GTX1-3, C1+C2 and B1, and dcGTX2+3. In spiny lobsters depurated with non-toxic squid, the mildly toxic N-sulfocarbamoyl toxins tended to transform into more highly toxic carbamates. After being fed toxic C. nobilis for six days, spiny lobsters selectively accumulated N-sulfocarbamoyl toxins with low toxicity. The concentration of dcGTX $(2+3)$ in P. stimpsoni decreased significantly and was not detectable after six days depuration, which was likely due to their initial low level of toxicity.

Xanthid crabs can harbor toxins [176] in their tissues at concentrations (Table 4) that would be fatal to other animals [177]. Maximum toxin levels of more than $16,000 \mu \mathrm{g}$ STX eq/100g were found in the xanthid crab Atergatis floridus in Australia, even though the majority of samples contained less than $80 \mu \mathrm{g} \mathrm{STX/100g} \mathrm{[161].} \mathrm{In} \mathrm{Japan,} \mathrm{an} \mathrm{individual} \mathrm{Zosimus} \mathrm{aeneus} \mathrm{contained} \mathrm{nearly} \mathrm{16,500} \mathrm{Mouse} \mathrm{Units}$ (MU) per g [178], which is equivalent to $300,000 \mu \mathrm{g} \mathrm{STX} \mathrm{eq/100g} \mathrm{[105,} \mathrm{161].} \mathrm{Several} \mathrm{species} \mathrm{of}$ xanthid crabs produce a hemolymph protein, saxiphilin, that binds with STX and which may confer some resistance to possible toxic effects [177]. This mechanism may explain why some xanthid crab species appear to tolerate exceptionally high levels of toxins [177]. When a mixture of GTX2 and GTX 3 in $3 \% \mathrm{NaCl}$ was injected into the right chela of $A$. floridus, the rate of dissipation within the crab was fairly high and suggested that high concentrations of toxin are not accumulated in all species [179]. 
Table 4. Maximum STX concentrations, microalgal sources, and geographical reports of STXs in crustaceans.

\begin{tabular}{|c|c|c|c|c|}
\hline $\begin{array}{c}\text { Crustacean species and } \\
\text { presumptive microalgal source }\end{array}$ & Common name & Maximum STX(s) concentration & Location & Reference \\
\hline \multicolumn{5}{|l|}{ Alexandrium catenella } \\
\hline Cancer magister & Dungeness crab & $72 \mu \mathrm{g}$ STX eq. $/ 100 \mathrm{~g}$ viscera & Washington, USA & 85 \\
\hline Cancer productus & Red rock crab & $\begin{array}{l}285 \mu \mathrm{g} \text { STX eq. } / 100 \mathrm{~g} \text { viscera } \\
27 \mu \mathrm{g} \text { STX eq. } / 100 \mathrm{~g} \text { muscle }\end{array}$ & Washington, USA & 161 \\
\hline Fabia subquadrata & Pea crab & $32 \mu \mathrm{g}$ STX eq. $/ 100 \mathrm{~g}$ whole crabs & Washington, USA & 85 \\
\hline Hemigrapsus nudus & Purple shore crab & $\begin{array}{l}44 \mu \mathrm{g} \text { STX eq. } / 100 \mathrm{~g} \text { whole body } \\
\text { minus legs and carapace }\end{array}$ & Washington, USA & 161 \\
\hline Hemigrapsus oregonensis & Green shore crab & $31 \mu \mathrm{g}$ STX eq. $/ 100 \mathrm{~g}$ whole & Washington, USA & 161 \\
\hline Pagurus sp. & Hermit crab & $35 \mu \mathrm{g}$ STX eq. $/ 100 \mathrm{~g}$ whole crabs & Washington, USA & 85 \\
\hline Pugettia producta & Northern kelp crab & $\begin{array}{l}146 \mu \mathrm{g} \text { STX eq. } / 100 \mathrm{~g} \text { eggs; } \\
1710 \mu \mathrm{g} \text { STX eq. } / 100 \mathrm{~g} \text { viscera; } \\
48 \mu \mathrm{g} \text { STX eq. } / 100 \mathrm{~g} \text { muscle }\end{array}$ & Washington, USA & 161 \\
\hline Balanus spp. & Barnacles & $84 \mu \mathrm{g}$ STX eq. $/ 100 \mathrm{~g}$ whole & Washington, USA & 161 \\
\hline \multicolumn{5}{|l|}{ Alexandrium tamarense } \\
\hline Anonyx sarsi & $\begin{array}{l}\text { Gammarid } \\
\text { amphipod }\end{array}$ & $\begin{array}{l}180 \mu \mathrm{g} \text { STX eq./100g (tissue not } \\
\text { specified) }\end{array}$ & St.Lawrence estuary, Canada & 162 \\
\hline Cancer borealis & Jonah crab & $\begin{array}{l}56 \mu \mathrm{g} \text { STX eq. } / 100 \mathrm{~g} \text { (tissue not } \\
\text { specified) }\end{array}$ & Maine, USA & 85 \\
\hline Homarus americanus & American lobster & $\begin{array}{l}1512 \mu \mathrm{g} \text { STX eq. } / 100 \mathrm{~g} \text { hepato- } \\
\text { pancreas (bioassay); } 961 \mu \mathrm{g} \text { STX } \\
\text { eq. } / 100 \mathrm{~g} \text { hepatopancreas (HPLC); } \\
69 \mu \mathrm{g} \text { STX eq. } / 100 \mathrm{~g} \text { meat (HPLC) }\end{array}$ & Bay of Gaspe, Canada & 162 \\
\hline \multicolumn{5}{|l|}{ Pyrodinium bahamense } \\
\hline ND & Crab & $339 \mathrm{MU}^{*} 100 \mathrm{~g}^{-1}$ & Brunei Darussalam & 141 \\
\hline
\end{tabular}




\begin{tabular}{|c|c|c|c|c|}
\hline ND & Mangrove crabs & $\begin{array}{l}239 \mathrm{MU} 100 \mathrm{~g}^{-1} \text { guts; } 175 \mathrm{MU} 100 \mathrm{~g}^{-1} \\
\text { gills }\end{array}$ & Sabah, Malaysia & 138 \\
\hline \multirow[t]{2}{*}{ Portunus pelagicus } & Blue manna crab & $\begin{array}{l}175 \mathrm{MU} 100 \mathrm{~g}^{-1} \text { whole crab; } 288 \mathrm{MU} \\
100 \mathrm{~g}^{-1} \text { gills; } 328 \mathrm{MU} 100 \mathrm{~g}^{-1} \text { guts }\end{array}$ & Sabah, Malaysia & 138 \\
\hline & & $1.8 \mu \mathrm{g}$ STX eq. $/ 100 \mathrm{~g}$ whole & Northwest Australia & 147 \\
\hline Panulirus versicolor & Painted spiny lobster & $\begin{array}{l}175 \mathrm{MU} 100 \mathrm{~g}^{-1} \text { whole lobster; } 175 \\
\text { MU } 100 \mathrm{~g}^{-1} \text { body only }\end{array}$ & Sabah, Malaysia & 138 \\
\hline Panulirus longipes & $\begin{array}{l}\text { Longlegged spiny } \\
\text { lobster }\end{array}$ & $\begin{array}{l}211 \mathrm{MU} 100 \mathrm{~g}^{-1} \text { whole lobster; } 177 \\
\text { MU } 100 \mathrm{~g}^{-1} \text { head and legs }\end{array}$ & Sabah, Malaysia & 138 \\
\hline ND & Penaeid shrimp & $\begin{array}{l}175 \text { MU } 100 \mathrm{~g}^{-1} \text { frozen tails; } \\
268 \mathrm{MU} 100 \mathrm{~g}^{-1} \text { body only }\end{array}$ & Sabah, Malaysia & 138 \\
\hline ND & $\begin{array}{l}\text { Penaeid shrimp } \\
\text { "Udang" }\end{array}$ & $190 \mathrm{MU} 100 \mathrm{~g}^{-1}$ & Brunei Darussalam & 141 \\
\hline \multicolumn{5}{|l|}{ Unknown origin } \\
\hline Hemigrapsus sanguineus & Asian shore crab & $0.16 \mathrm{MU} \mathrm{g}^{-1}$ hepatopancreas & Sanriku coast, Japan & 146 \\
\hline Metopograpsus frontalis & $\begin{array}{l}\text { Mangrove shore } \\
\text { crab }\end{array}$ & $10.0 \mu \mathrm{g}$ STX eq. $/ 100 \mathrm{~g}$ whole & Northwest Australia & 147 \\
\hline Pachygrapsus crassipes & Striped shore crab & $0.10 \mathrm{MU} \mathrm{g}^{-1}$ hepatopancreas & Sanriku coast, Japan & 146 \\
\hline Percnon planissimum & Sally lightfoot crab & 7.4 $\mathrm{MU} \mathrm{g}^{-1}$ whole & Ishigaki Island, Japan & 52 \\
\hline Pilumnus pulcher & Hairy crab & $80 \mu \mathrm{g}$ STX eq. $/ 100 \mathrm{~g}$ whole & Northwest Australia & 147 \\
\hline \multirow[t]{2}{*}{ Pilumnus vespertilio } & Hairy crab & $120 \mu \mathrm{g}$ STX eq. $/ 100 \mathrm{~g}$ whole & Northwest Australia & 147 \\
\hline & & 6.1 $\mathrm{MU} \mathrm{g}^{-1}$ whole & Ishigaki Island, Japan & 52 \\
\hline Schizophrys aspera & Eyelash spider crab & $2.3 \mathrm{MU} \mathrm{g}^{-1}$ whole & Ishigaki Island, Japan & 52 \\
\hline Telmessus acutidens & Edible shore crab & $2723 \mu \mathrm{g}$ STX eq. $/ 100 \mathrm{~g}$ viscera & Fukushima Prefecture, Japan & 163,164 \\
\hline Actaeodes tomentosus & Xanthid crab & $130 \mathrm{MU} \mathrm{g}^{-1}$ whole & Ishigaki Island, Japan & 52 \\
\hline \multirow[t]{2}{*}{ Atergatis floridus } & Xanthid crab & Positive STX, NEO, GTX2 & Fiji Islands & 165 \\
\hline & & $16,611 \mu \mathrm{g}$ STX eq. $/ 100 \mathrm{~g}$ whole & Northwest Australia & 147 \\
\hline
\end{tabular}




\begin{tabular}{|c|c|c|c|c|}
\hline & & $490 \mathrm{MU} \mathrm{g}^{-1}$ whole & Ishigaki Island, Japan & 52 \\
\hline & & Positive GTX 1-4 & Taiwan & 166 \\
\hline Atergatopsis germaini & Xanthid crab & Positive GTX 3, NEO, STX & Taiwan & 167 \\
\hline Demania reynaudi & Xanthid crab & Positive GTX 3-4, NEO & Taiwan & 166 \\
\hline Eriphia scabricula & Xanthid crab & $180 \mathrm{MU} \mathrm{g}^{-1}$ whole & Ishigaki Island, Japan & 52 \\
\hline Eriphia sebana & Xanthid crab & Positive STX, NEO, GTX1, GTX2 & Great Barrier Reef, Australia & 168 \\
\hline Euzanthus exsculptus & Xanthid crab & $29 \mu \mathrm{g}$ STX eq. $/ 100 \mathrm{~g}$ whole & Northwest Australia & 147 \\
\hline Lophozozymus octodentatus & Xanthid crab & $23 \mu \mathrm{g}$ STX eq. $/ 100 \mathrm{~g}$ whole & Northwest Australia & 147 \\
\hline \multirow[t]{2}{*}{ Lophozozymus pictor } & Xanthid crab & 18.9 $\mathrm{MU} \mathrm{g}^{-1}$ whole crab & Australia & 169 \\
\hline & & Positive GTX & Taiwan & 170 \\
\hline \multirow[t]{2}{*}{ Neoxanthias impressus } & Xanthid crab & $147 \mu \mathrm{g}$ STX eq./100g whole & Northwest Australia & 147 \\
\hline & & $10 \mathrm{MU} \mathrm{g}^{-1}$ whole & Ishigaki Island, Japan & 52 \\
\hline Platypodia granulosa & Xanthid crab & $110 \mathrm{MU} \mathrm{g}^{-1}$ whole & Ishigaki Island, Japan & 52 \\
\hline Platypodia pseudogranulosa & Xanthid crab & $10 \mu \mathrm{g}$ STX eq. $/ 100 \mathrm{~g}$ whole & Northwest Australia & 147 \\
\hline Xanthias lividus & Xanthid crab & Positive GTX & Taiwan & 171 \\
\hline \multirow[t]{6}{*}{ Zosimus aeneus } & Xanthid crab & Positive STX, NEOSTX, GTXI-3 & Fiji Islands & 165 \\
\hline & & Positive GTX & Taiwan & 171 \\
\hline & & $660 \mathrm{MU} \mathrm{g}^{-1}$ whole & Ishigaki Island, Japan & 52 \\
\hline & & $\begin{array}{l}108,000 \mu \mathrm{g} \text { STX eq. } / 100 \mathrm{~g} \text { chelae } \\
\text { muscle; } 720 \mu \mathrm{g} \text { STX eq. } / 100 \mathrm{~g} \\
\text { cephalothorax muscle }\end{array}$ & Japan & 172 \\
\hline & & $78 \mu \mathrm{g}$ STX eq./100g whole & Northwest Australia & 147 \\
\hline & & $259 \mathrm{MU} \mathrm{g}^{-1}$ whole crab & Philippines & 173 \\
\hline Procambarus clarkii & Red swamp crayfish & $0.23 \mathrm{MU} \mathrm{g}^{-1}$ hepatopancreas & Sanriku, Japan & 146 \\
\hline Carcinoscorpius rotundicauda & $\begin{array}{l}\text { Mangrove horseshoe } \\
\text { crab }\end{array}$ & STX & Thailand & 174 \\
\hline
\end{tabular}

* $\mathrm{MU}=$ mouse units $(1 \mathrm{MU}=0.18 \mu \mathrm{gSTX}) ; \mathrm{ND}=$ no data 


\subsubsection{Case Study 3: STXs in Crabs}

East Timor - In October 2000, an adult male died within hours of ingesting a xanthid crab Zosimus aeneus (Xanthidae) [172]. A second, yet uneaten specimen of $Z$. aeneus from the same meal contained a total toxicity of $162.8 \mu \mathrm{g}$ STX eq/100g tissue (comprising GTX2, GTX3, NEO, dcSTX, and STX); these same toxins were identified in the gut contents, blood, liver and urine of the victim. Metabolism of STXs occurred with the ingested crab harboring GTX2, GTX3 and STX, whereas NEO, dcSTX and STX dominated the STXs in the victim's urine. The STX(s) composition in the gut contents, in both their identity and proportion, was intermediate between the eaten crab and the urine suggesting that toxin conversion commenced in the victim's gut. The victim's meal did not consist solely of the toxic crab eaten and the possibility of other food items acting in a synergistic manner with the consumed STXs cannot be discounted. As well as STXs, xanthid crabs are known to harbor tetrodotoxin (TTX) and palytoxin [180-182].

Japan - Oikawa et al. [163-164, 183-184] showed that the edible crab Telmessus acutidens both accumulated and retained STXs after consuming contaminated mussels (Mytilus galloprovincialis) in Japan. STXs in two shore crab species, T. acutidens and Charybdis japonica, were compared with the toxin in the prey mussel M. galloprovincialis and causative dinoflagellates Alexandrium tamarense, all having been collected at Onahama, Fukushima Prefecture, in the northern part of Japan. When the toxicities were detected in mussels by mouse bioassays, $73.7 \%$ of the sampled $T$. acutidens were toxic in the hepatopancreas. Charybdis japonica was also expected to be a possible vector species, but only small quantities of STXs were detected in eight specimens of the crab by HPLC analysis. The difference in $\operatorname{STX}(\mathrm{s})$ accumulation in both $T$. acutidens and $C$. japonica was then investigated at Onahama, Fukushima Prefecture, from 2002 to 2005. The level of toxin accumulation in the hepatopancreas of $T$. acutidens corresponded to that of mussels when examined on a yearly basis. In 2003, some crabs had a high toxicity of approximately 1000 MU, which compares to one-third of the human minimum lethal dose. Therefore, it was concluded by the authors, that $T$. acutidens should be monitored as a vector species of PSP toxins. The toxin profile of T. acutidens was also investigated. Because an increase in highly toxic species of STXs with a decrease in low toxic species, such as $N$ sulfocarbamoyl-11-hydroxysulfate toxins, was not clearly observed between consecutive samples, toxin transformation in T. acutidens was considered to have a minimal impact on toxicity. STXs were also detected in several specimens of $C$. japonica, but the highest toxicity was only $7.4 \mathrm{MU} / \mathrm{g}$ in the hepatopancreas. Lastly, accumulation and depuration rates of STXs in the crab T. acutidens were investigated by feeding toxic and non-toxic mussels under laboratory controlled conditions. The crab accumulated toxins in the hepatopancreas in proportion to the amount of toxic mussels they ingested, and the toxicity in the crab hepatopancreas became 3.2 fold of that in the prey mussels after 20 days of feeding. During depuration, a fast reduction of the total toxicity was observed in the crab, and the retention rate of the toxicity after five days depuration with feeding of non-toxic mussels was $45.8+/$ $18.7 \%$. The reduction of the toxicity was moderated in the later period of depuration, and the retention rates of the total toxicity after 10 and 20 days were $54.1+/-29.8 \%$ and $14.5+/-9.0 \%$, respectively. The toxin profiles in the crab and mussel were investigated by high performance liquid chromatography, and reductive conversions of the toxins were observed when the toxins were 
transferred from the mussel to the crab. Consequently, high concentrations of GTX2, GTX3, and STX that were not detected in the prey mussels were found in the crab.

Alaska, USA - Although not thoroughly recorded in the scientific literature, the State of Alaska, Division of Environmental Health, Food Safety and Sanitation Program has been observing elevated levels of STXs in viscera from several species of commercially harvested crabs for years (Figure 1). PSP is endemic to the coastal communities of the State of Alaska [185]. The high frequency of STX producing dinoflagellates coupled with an extensive seafood harvesting industry prompted the state to establish a STX monitoring program. Most commercially harvested crab in Alaska is landed in the open waters of the Bering Sea, but limited harvesting does occur in areas where PSP toxicity is commonly seen in filter-feeding bivalves. In these areas, high regional and species variability in crab STX(s) content exists, with Dungeness crab (Cancer magister) from Kodiak Island appearing to be a consistent food safety concern (Figure 1,2). To protect public safety, the State of Alaska Food Safety and Sanitation Program, Department of Environmental Conservation, and the Department of Fish and Game perform both pre-season environmental sampling and in season monitoring of both harvesting areas and harvested product. A conservative action level of $70 \mu \mathrm{g}$ STX eq. $/ 100 \mathrm{~g}$ viscera (FDA regulatory action level $=80 \mu \mathrm{g}$ STX eq. $/ 100 \mathrm{~g}$ tissue) has been established above which product cannot be marketed either live or whole cooked but must be eviscerated at the processing facility where it is landed (http://www.dec.state.ak.us/eh/fss/seafood/PSP/dungeness.htm [accessed 3 March, 2008]). Due to the success of this monitoring program, no reports of PSP due to the consumption of commercially harvested crab have been reported even though visceral concentrations exceeding 500 $\mu \mathrm{g}$ STX eq./100 g have been observed almost yearly in some areas (Figure $2 \mathrm{~b}$ ).

\subsection{Other invertebrates}

Other, non-molluscan invertebrates that accumulate STXs include annelid tubeworms Eudistylia sp. [161], and echinoderm starfish Asterias amurensis, Astropecten scoparius, A. polyacanthus, and Pisaster ochraceus [161, 186-187]. Thus far, these species have not been implicated in PSP cases.

\subsection{Fish}

Although not usually targeted, STXs have been incidentally found in numerous species of fish (Table 5). As with shellfish, because STXs are water soluble compounds, researchers believed that cold-blooded vertebrates such as finfish did not typically accumulate STX(s) nor were fish negatively affected by STXs [131]. However, the transport of STXs through the food chain and the vectoring and accumulation of toxins through zooplankton have been identified as important mechanisms by which toxins become available to higher trophic levels such as fish [188-193].

As they are in bivalves, the toxic profiles of STXs that accumulate in fish are likely to be partially determined by species-specific differences in the bioconversion process or are dependent upon the variety and toxin profiles of their toxic prey species. During July 1988, a small bloom of Alexandrium fundyense occurred in southwestern Bay of Fundy, New Brunswick, Canada. The highest concentration in a surface-water sample was $7.5 \times 10^{3}$ cells/L. Concentrations of STXs in Atlantic mackerel, Scomber scombrus, liver extracts were measured by mouse bioassay and ranged from 40 - 
$209 \mu \mathrm{g}$ STXeq/100g wet weight. By far the dominant component in mackerel liver was STX except in a few fish where NEO was also dominant. GTX2 and GTX3, and rarely B2, were also detectable. The difference between the toxic profiles of the fish and $A$. fundyense was attributed to the variety of toxic prey consumed by the fish. The fact that mackerel accumulate STXs demonstrates the transfer of these toxins up the food chain [194-195, 207]. Atlantic mackerel in the Gulf of Lawrence retained STX, GTX2, and GTX3 all year round and progressively accumulated STXs throughout their life, likely vectored via zooplankton feeding on toxic Alexandrium [195].

Figure 1. (A) Map of the state of Alaska, U.S.A. indicating collection sites for crab STX testing. (B) Number of samples above and below the regulatory action limit of $80 \mu \mathrm{g}$ STX eq./100 g tissue for all species of commercially harvested crab in Alaska between 19922004 , broken down by major testing area. All values are for crab viscera only. Sample $=1$ crab. All testing done by AOAC mouse bioassay.

A.
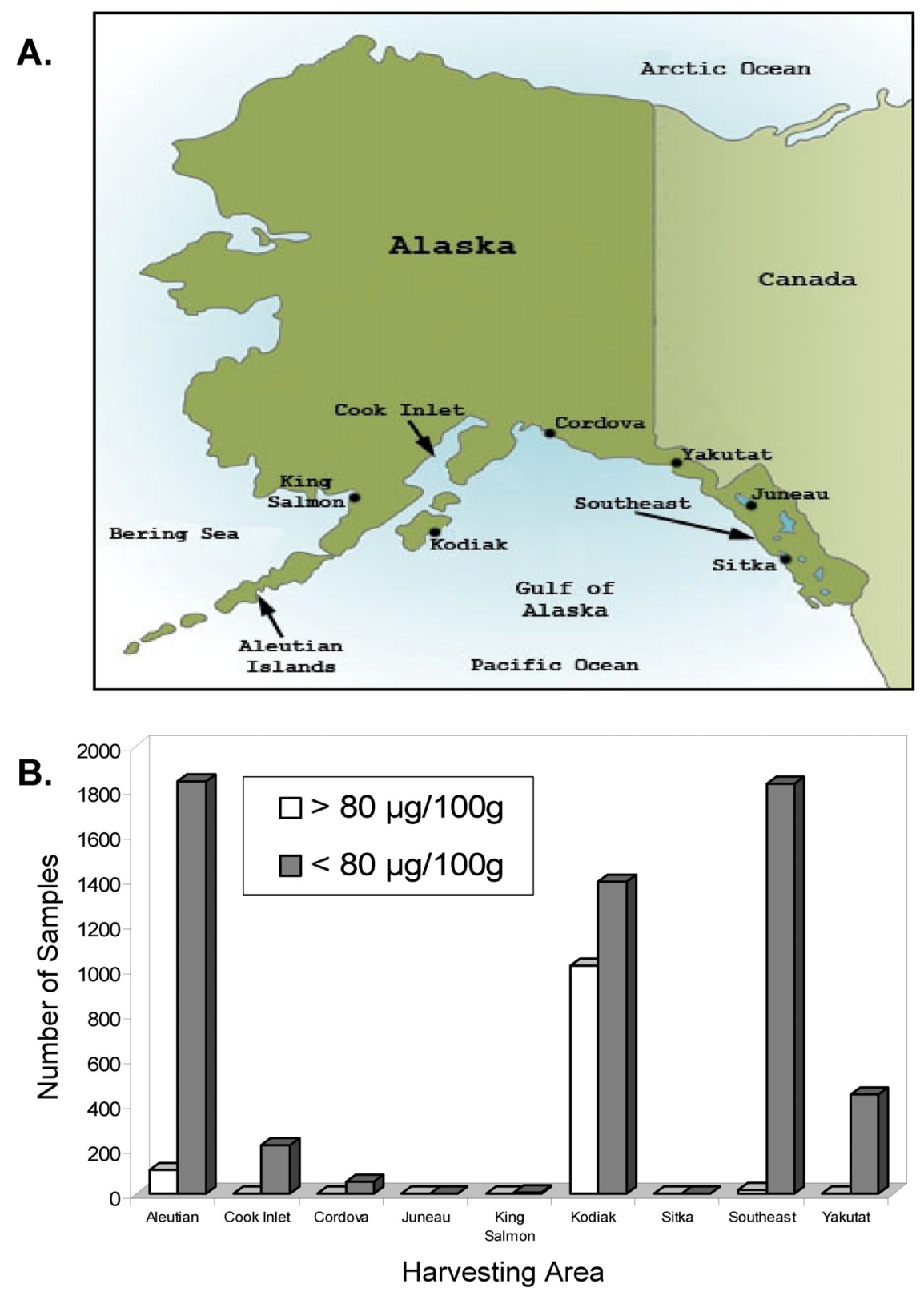
Figure 2. (A) Number of samples above and below the regulatory action limit of $80 \mu \mathrm{g}$ STX eq./100 g tissue for commercially harvested crab in Alaska between 1992-2004 for all testing areas, broken down by crab type: Dungeness (Cancer magister), Tanner: (Chionoecetes opilio and Chionoecetes bairdi), King Crab: (Red, Paralithodes camtschaticus; Blue, Paralithodes platypus; Brown, Lithodes aequispinus), and Miscellaneous (including minced, viscera, and Hair Crab, Erimacrus isenbeckii). (B) Total STXs (in $\mu \mathrm{g}$ STX equivalents/100 g viscera) for all commercially harvested crab species in Alaska for all areas from 1992-2004.

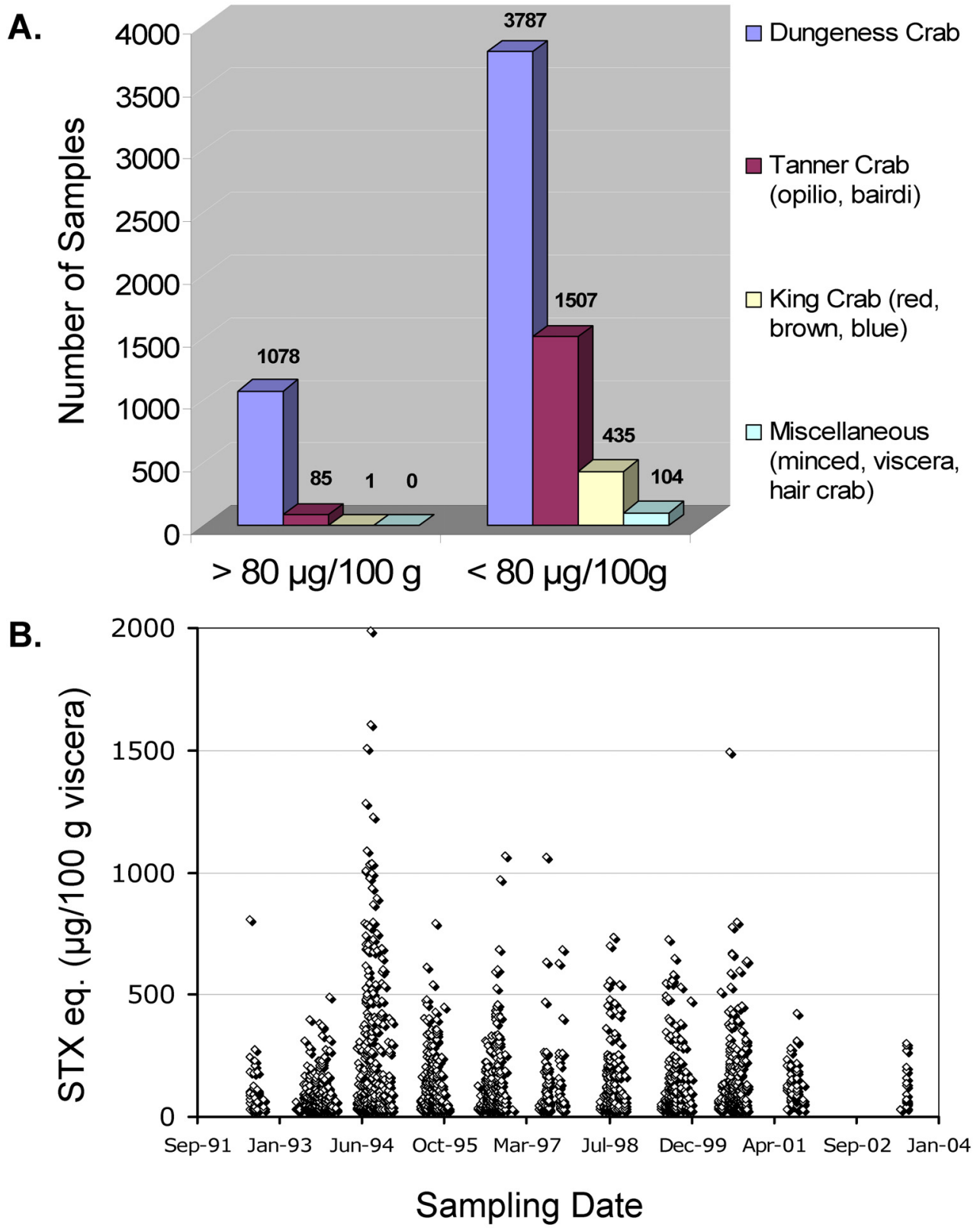


Table 5. Maximum STX concentrations, microalgal sources, and geographical reports of STXs in various fish tissues and species.

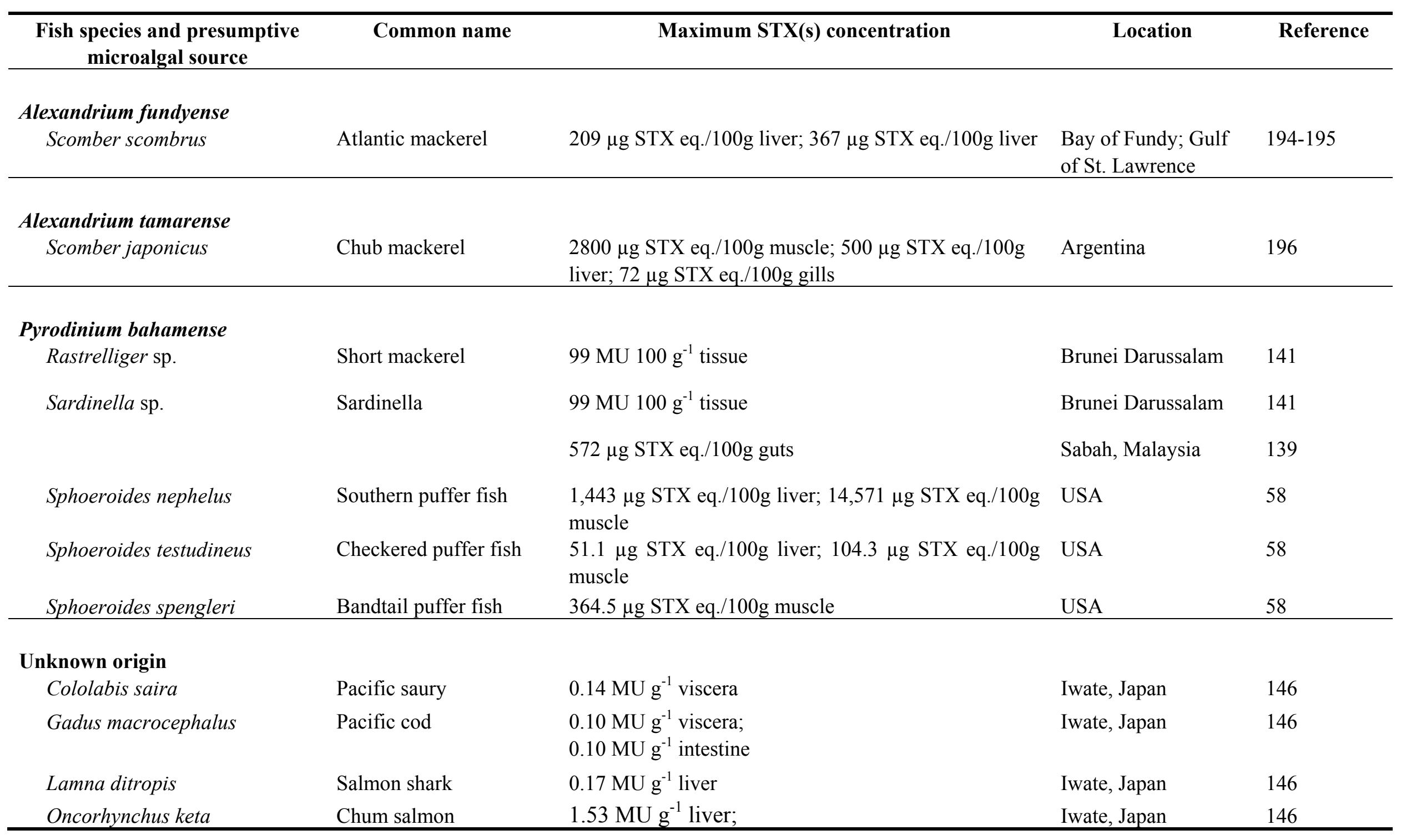




\begin{tabular}{|c|c|c|c|c|}
\hline Scarus (= Ypsiscarus) ovifrons & Knobsnout parrotfish & $\begin{array}{l}0.69 \mathrm{MU} \mathrm{g}^{-1} \text { viscera } \\
0.26 \mathrm{MU} \mathrm{g}^{-1} \text { liver; } \\
1.58 \mathrm{MU} \mathrm{g}^{-1} \text { intestine }\end{array}$ & Iwate, Japan & 146 \\
\hline Arothron firmamentum & Starry toadfish & $740 \mathrm{MU} \mathrm{g}^{-1}$ ovary & Japan & 197 \\
\hline A. mappa & Map puffer & Positive STX in liver, muscle, skin, and intestine & Philippines & 198 \\
\hline A. manillensis & Narrow-lined puffer & Positive STX in liver, muscle, skin, and intestine & Philippines & 198 \\
\hline A. reticularis & Reticulated puffer & Positive STX in liver, muscle, skin, and intestine & Philippines & 198 \\
\hline A. stellatus & Starry toadfish & Positive STX in liver, muscle, skin, and intestine & Philippines & 198 \\
\hline \multirow[t]{2}{*}{ Chelonodon patoca } & Milk-spotted puffer & $\begin{array}{l}22.0 \mathrm{MU} \mathrm{g}^{-1} \text { muscle; } 40 \mathrm{MU} \mathrm{g}^{-1} \text { skin; } 12.0 \mathrm{MU} \mathrm{g}^{-1} \\
\text { liver; } 2.8 \mathrm{MU} \mathrm{g}^{-1} \text { ovary (data shown as mean) }\end{array}$ & Bangladesh & 199 \\
\hline & & Positive STX in liver, muscle, skin, and intestine & Philippines & 198 \\
\hline Colomesus asellus & Amazon puffer & 53.2 MU whole body & Brazil & 200 \\
\hline T. vermicularis & Purple puffer & Positive for STX in liver, ovary and digestive tract & Japan & 202 \\
\hline \multirow[t]{2}{*}{ Tetraodon cutcutia } & Ocellated puffer & $\begin{array}{l}\text { 7.6 } \mathrm{MU} \mathrm{g} \mathrm{g}^{-1} \text { muscle; } 20 \mathrm{MU} \mathrm{g}^{-1} \text { skin; } 6.0 \mathrm{MU} \mathrm{g}^{-1} \text { liver; } \\
\text { 5.6 } \mathrm{MU} \mathrm{g}^{-1} \text { ovary (data shown as mean) }\end{array}$ & Thailand & 199 \\
\hline & & $\begin{array}{l}182 \mathrm{MU} 100 \mathrm{~g}^{-1} \text { skin; } 238 \mathrm{MU} 100 \mathrm{~g}^{-1} \text { muscle; } 106 \mathrm{MU} \\
100 \mathrm{~g}^{-1} \text { liver }\end{array}$ & Bangladesh & 203 \\
\hline T. cochinchinensis (as T. fangi) & Puffer & Positive for STX whole body & Thailand & 204 \\
\hline T. suvatii & Arrowhead puffer & $\begin{array}{l}191 \mathrm{MU} \mathrm{g}^{-1} \text { muscle; } 230 \mathrm{MU} \mathrm{g}^{-1} \text { skin; } 174 \mathrm{MU} \mathrm{g}^{-1} \\
\text { liver; } 117 \mathrm{MU} \mathrm{g}^{-1} \text { egg }\end{array}$ & Thailand & 205 \\
\hline T. turgidus & Brown puffer & $\begin{array}{l}<2 \mathrm{MU} \mathrm{g}^{-1} \text { muscle; } 37 \mathrm{MU} \mathrm{g}^{-1} \text { skin; }<2 \mathrm{MU} \mathrm{g}^{-1} \text { liver; } \\
27 \mathrm{MU} \mathrm{g}^{-1} \text { ovary }\end{array}$ & Cambodia & 206 \\
\hline
\end{tabular}

\footnotetext{
$* \overline{\mathrm{MU}}=$ mouse units $(1 \mathrm{MU}=0.18 \mu \mathrm{gSTX})$
} 
Fish, with the exception of puffer fish (see case study 5 below) are not usually vectors for STX(s) transfer if humans only eat the muscle. Accumulation of STXs is usually confined to the fish's gut, and either certain species perish before detectable amounts of toxin appear in the muscle [207-208] or negligible concentrations of toxins accumulate in the muscle. In experimental studies, several fish species challenged with oral $\left(\mathrm{LD}_{50}=400-750 \mu \mathrm{g} / \mathrm{kg}\right.$ body weight) or i.p. (intraperitoneal) $(4-12 \mu \mathrm{g} / \mathrm{kg}$ body weight) doses of STX showed similar symptoms: loss of equilibrium; gasping; reduced locomotor activity; short, irregular, hyperactive periods; and death within one hour. Heavy accumulation of STX was confined to the gut (340-840 $\mu \mathrm{g}$ per 100g tissue), while STX occurred in the muscle tissues at a level an order of magnitude lower than in the gut [208]. Kwong et al. [209] exposed green-lipped mussels Perna viridis and black sea bream Acanthopagrus schlegeli to toxic Alexandrium fundyense to evaluate the accumulation, distribution, transformation, and elimination of STXs in controlled experimental conditions. Mussels were fed A. fundyense for seven days followed by three weeks of depuration, and the fish were fed toxic clams for five days followed by two weeks of depuration. The fish viscera accumulated most of the STXs. In the fish, the ratio of C1/C2 was 3.0 times $(p<0.01)$ higher when compared to the mussel tissues, indicating that conversion from $\mathrm{C} 2$ to $\mathrm{C} 1$ might have occurred when the toxin was transferred from the clams to the fish. Jiang et al. [210] investigated the transmission and transformation of STXs from A. tamarense to the cladoceran Moina mongolica and subsequently to the larval fish Sciaenops ocellatus. STXs were transferred to $S$. ocellatus when they preyed upon STX(s)-containing M. mongolica. During the experimental period, $A$. tamarense, M. mongolica and the larval fish's digestive glands contained $\mathrm{C} 1$ and $\mathrm{C} 2$ toxins, while the viscera of $S$. ocellatus contained NEO. The proportion of $\mathrm{C} 2$ to $\mathrm{C} 1$ toxins increased when STXs were transferred from $A$. tamarense to $M$. mongolica, but in the subsequent transfer from M. mongolica to $S$. ocellatus the proportion of $\mathrm{C} 1$ to $\mathrm{C} 2$ toxins increased. During depuration, the contents of $\mathrm{C} 1$ and $\mathrm{C} 2$ toxins in fish larvae decreased with the duration of depuration, but NEO remained relatively constant. The present results indicated that, using a cladoceran as the vector, STXs can be transferred from toxic algae to a high trophic level fish and metabolized in the fish. Future work should address the metabolic characteristics of STXs in cladocerans and the end result when they are transferred to fishes.

\subsubsection{Case study 4: STXs in planktivorous fish}

Far East - With the puffer fish exception, because STXs do not typically accumulate in fish muscle, humans who consume only the muscle are unlikely to become intoxicated. However, those those who consume whole fish and eat the viscera are likely to become sick. In 1976 in Brunei, 14 nonfatal PSP cases were associated with the consumption of the planktivorous fish Rastrelliger sp. during a bloom of Pyrodinium bahamense var. compressum [48]. One PSP incident in 1983 in Indonesia involved 191 cases and four human fatalities due to the consumption of the planktivorous clupeoid fish Sardinella spp. and Selaroides leptolepis. In a second incident in November 1983, 45 people became ill after consuming fish and suffered numbness, dizziness, and tingling sensations of the lips, tongue, and throat. Although no known toxic dinoflagellate was associated with the event [100], PSP was highly suspected [211]. STXs with toxin profiles similar to Pyrodinium bahamense have been confirmed in gut contents of Sardinella sp. from Brunei [41] and in PSP incidents involving Pyrodinium, toxic shellfish, and fish that were reported from the Philippines [211]. These incidents likely occurred 
because it is customary in south-east Asia to eat small fish whole, including any potentially toxic viscera [211-212].

\subsubsection{Case study 5: STXs in puffer fish}

One exception to the general rule that STXs tend not to accumulate to levels associated with human intoxication in fish muscle is in members of the family Tetraodontidae (puffer fish) (Table 5) inhabiting marine and freshwater habitats. STX was first described as a minor component of highly toxic (with TTX) Takifugu pardalis livers in Japan [201]. Soon after, STX was confirmed as a minor component in the additional Japanese species $T$. poecilonotus and $T$. vermicularis [202], and as a major toxin in Arothron firmamentum [197]. STXs were found to be the sole toxic component in a range of freshwater puffer fish, some responsible for human poisoning events, in Thailand, Bangladesh, Brazil, and in Cambodia (Table 5). Seven species of marine puffer fish in the Philippines (Table 5) were found to contain both STXs and TTX, with STXs being the dominant toxin in several species [198].

Florida, USA - Puffer fish became an important source of protein on the east coast of the United States during the Second World War, and supported a commercial fishery in the decades that followed. The primary species landed was the northern puffer fish (Sphoeroides maculatus) but limited numbers of the southern puffer (S. nephelus), primarily from Florida, was also harvested [213]. The industry was centered in the mid-Atlantic states of Virginia, Maryland, New York, and New Jersey with $>$ 6,000 metric tons landed in 1965 (National Marine Fisheries Service Statistics and Economics Division, personal communication). Fish were marketed dressed and skinned under the name "sea squab". Although the commercial puffer fish industry has steadily declined since the 1970's, today being only harvested as by-catch, domestic puffer fish can still be found in some U.S. fresh fish markets. In addition, an average of $>500,000$ fish was caught annually between 1981 and 2003 by recreational anglers in the U.S. where they are easily obtained by a range of gear including hook and line (National Marine Fisheries Service Statistics and Economics Division, personal communication [213]).

In January 2002, the poison control center in Tampa, Florida, USA received a report of a man hospitalized with symptoms of numbness and tingling of the hands, vomiting, and diarrhea after consuming puffer fish caught during a recreational fishing trip near Titusville, located on the northern Indian River Lagoon (IRL) on Florida's central east coast [214]. After additional reports of patients with symptoms of neurological illness from Virginia and New Jersey, all associated with what was believed to be $S$. nephelus originating from the northern IRL, uneaten fish muscle samples from the New Jersey incident sent to the Canadian Institute for Marine Biosciences by the New Jersey Department of Health were, surprisingly, found to contain no detectable TTX but to contain significant amounts of STX, with lesser amounts of the STX congeners B1, and dcSTX [215]. This same combination of toxins was confirmed in meal remnants from two separate poisoning events in 2004 [216]. In total, 28 cases of SPFP were reported from 2002-2004 -- all due to fish originating from the northern IRL [58]. These were the first reports of STXs both in Florida marine waters and in indigenous puffer fish in the U.S. In April 2002, the Florida Fish and Wildlife Conservation 
Commission (FWC) placed a ban on the commercial and recreational harvesting of all puffer fish species for the entire IRL. At the same time, the FWC initiated intensive sampling for STXs in multiple species of aquatic biota in Florida's coastal waters with emphasis on the IRL. Partial results of this sampling were reported [58, 217]. Analysis of IRL puffer fish found concentrations of STXs in muscle often well in excess of the $80 \mu \mathrm{g}$ STX eq./100 g tissue regulatory action limit set for shellfish. After extended monitoring, STX concentrations in puffer muscle in certain regions of the IRL remained well above the action limit. As a result, the puffer fishing ban in the IRL was made indefinite in June 2004. Based on toxin profiles and abundance in the IRL during the first SPFP reports in 2002, Landsberg et al. [58] suggested the dinoflagellate Pyrodinium bahamense, not reported to produce STXs in Florida waters prior to 2002, as the putative toxin source.

Deeds et al. [218] confirmed that S. nephelus from the northern IRL contained elevated concentrations of STX in muscle $(1770 \pm 159 \mu \mathrm{g}$ STX/100g tissue) compared to liver $(609 \pm 432 \mu \mathrm{g}$ STX/100g tissue), with only low to non-detectable amounts of TTX in all tissues tested. The additional IRL puffer species $S$. testudineus (checkered puffer) and $S$. spengleri (bandtail puffer), known to only occur further south in the lagoon system, were found to contain significantly greater concentrations of TTX compared to STX in all tissues (maximum concentration for TTX found in S. testudineus livers $6076 \pm 3283 \mu \mathrm{g}$ TTX/100g tissue - maximum concentration of STX found in S. spengleri livers $74 \pm$ $42 \mu \mathrm{g} \mathrm{STX} / 100 \mathrm{~g}$ tissue). This work confirmed $S$. nephelus, a species not associated with toxicity in the IRL prior to these events, as the likely cause of all 28 cases of SPFP originating from the IRL during 2002-2004. These events on the east coast of the U.S. represented the first confirmed cases of puffer fish poisoning due solely to STX in North America.

\section{Conclusion}

In comparison to non-traditional (i.e. non-filter feeding) vectors for PSP, more is known about STX sources, routes of exposure, species specific and population specific sensitivities, depuration rates, compartmentalization, and biotransformations in filter-feeding bivalves. As a result, monitoring and management of traditional bivalve vectors for PSP are, in many cases, highly successful and result in the protection of public health. Due to a lack of basic knowledge on the source(s) and fate of STXs in non-traditional vectors, human intoxications due to the consumption of these species are often more unpredictable, and resource closures are often longer and sometimes indefinite. With the apparent expansion in STX producing microrganisms world-wide, an ever-increasing demand for seafood, and the emergence of seafood as an economic commodity for export, particularly in developing countries, more study is required on STX sources, distribution, and fate in these non-traditional PSP vectors to assure both public safety and consumer confidence on local, national, and international scales.

\section{References}

1. Oshima, Y. Chemical and enzymatic transformation of paralytic shellfish toxins in marine organisms. In Harmful Marine Algal Blooms; Lassus, P., Arzul, G., Erard-Le-Denn, E., Gentien, P., Marcaillou-Le-Baut, C., Eds.; Technique et Documentation, Lavoisier: Paris, 1995; pp. 475-480. 
2. Cembella, A. D.; Shumway, S. E.; Lewis, N.I. Anatomical distribution and spatio-temporal variation in paralytic shellfish toxin composition in two bivalve species from the Gulf of Maine. J. Shellfish Res. 1993, 12, 389-403.

3. Onodera, H. Y.; Oshima, Y.; Watanabe, M. F.; Watanabe, M.; Bolch, C. J.; Blackburn, S.; Yasumoto, T. Screening of paralytic shellfish toxins in freshwater cyanobacteria and chemical confirmation of the toxins in cultured Anabaena circinalis from Australia. In Harmful and Toxin Algal Blooms; Yasumoto, T., Oshima, Y., Fukuyo, Y., Eds.; Intergovernmental Oceanographic Commission of UNESCO: Paris, 1996; pp. 563-566.

4. Sullivan, J. J. Methods of analysis for algal toxins: dinoflagellate and diatom toxins. In Algal Toxins in Seafood and Drinking Water; Falconer, I. R., Ed.; Academic Press: London, 1993; pp. 29-48.

5. Onoue, Y.; Nozawa, K. Zinc-bound PSP toxins separated from Cochlodinium red tides. In Mycotoxins and Phycotoxins '88; Natori, S., Hashimoto, K., Ueno, Y., Eds.; Elsevier: Amsterdam, 1989; pp. 359-366.

6. Reyes-Vasquez, G.; Ferraz-Reyes, E.; Vasquez, E. Toxic dinoflagellate blooms in northeastern Venezuela during 1977. In Toxic Dinoflagellate Blooms; Taylor, D. L., Seliger, H. H., Eds.; Elsevier: New York, 1979; pp. 191-194.

7. Prakash, A.; Taylor, F. J. R. A red water bloom of Gonyaulax acatenella in the Straight of Georgia and its relation to paralytic shellfish toxicity. J. Fish. Res. Bd. Can. 1966, 23, 16251270 .

8. Schmidt, R. J.; Loeblich III, A. R. Distribution of paralytic shellfish poisoning among Pyrrhophyta. J. Mar. Biol. Assoc. U.K. 1979, 59, 479-487.

9. Cembella, A. D.; Sullivan, J. J.; Boyer, G. L.; Taylor, F. J. R.; Anderson, R. J. Variation in paralytic shellfish toxin composition within the Protogonyaulax tamarensis/catenella species complex; red tide dinoflagellates. Biochem. Syst. Ecol. 1987, 15, 171-186.

10. Ciminiello, P. E.; Fatturoso, E.; Fornio, M.; Montresor, M. A new PSP-like toxin in Alexandrium andersoni (Dinophyceae). Harmful Algae News 1999, 18, 1-3.

11. Ciminiello, P. E.; Fatturoso, E.; Fornio, M.; Montresor, M. Saxitoxin and neosaxitoxin as toxic principles of Alexandrium andersoni (Dinophyceae) from the Gulf of Naples, Italy. Toxicon 2000, 38, 1871-1877.

12. Taylor, F. J. R.; Fukuyo, Y.; Larsen, J. Taxonomy of harmful dinoflagellates. In Manual on Harmful Marine Microalgae; Hallegraeff, G. M., Anderson, D. M., Cembella, A. D., Eds.; UNESCO: Paris, 1995; pp. 283-317.

13. Schantz, E. J.; Lynch, J. M.; Vayvada, G.; Matsumoto, K.; Rapoport, H. The purification and characterization of the poison produced by Gonaulax catenella in axenic culture. Biochemistry 1966, 5, 1191-1195.

14. Proctor, N. H.; Chan, S. L.; Trevor, A. J. Production of saxitoxin by cultures of Gonyaulax catenella. Toxicon 1975, 13, 1-9.

15. Onone, Y.; Noguchi, T.; Hashimoto, K. Studies on paralytic shellfish poison from the oyster cultured in Senzaki Bay, Yamaguchi Prefecture. Nippon Suis. Gakk. 1980, 46, 1031-1034. 
16. Onone, Y.; Noguchi, T.; Maruyama, J.; Hashimoto, K.; Ikeda, T. New toxins separated from oysters and Protogonyaulax catenella from Senzaki Bay, Yamaguchi Prefecture. Nippon Suis. Gakk. 1981, 47, 1643.

17. Onone, Y.; Noguchi, T.; Maruyama, J.; Uneda, Y.; Hashimoto, K.; Ikeda, T. Comparison of PSP compositions between toxic oysters and Protogonyaulax catenella from Senzaki Bat, Yamaguchi Prefecture. Nippon Suis. Gakk. 1981, 47, 1347-1350.

18. Boyer, G. L.; Sullivan, J. J.; Anderson, R. J.; Harrison, P. J.; Taylor, F. R. J. Toxin production in three isolates of Protogonyaulax sp. In Toxic Dinoflagellates; Anderson, D. M., White, A. W., Baden, D. G., Eds.; Elsevier: New York, 1985; pp. 281-286.

19. Ogata, T.; Kodama, M. Ichthyotoxicity found in cultured media of Protogonyaulax spp. Mar. Biol. 1986, 92, 31-34.

20. Hallegraeff, G. M.; Bolch, C. J.; Blackburn, S. I.; Oshima, Y. Species of the toxigenic dinoflagellate genus Alexandrium in southeastern Australian waters. Bot. Mar. 1991, 34, 575587.

21. Kim, C. -H.; Sako, Y.; Ishida, Y. Comparison of toxin composition between populations of Alexandrium spp. from geographically distinct areas. Nippon Suisan Gakkaishi. 1993, 59, 641646.

22. Kodama, M.; Ogata, T.; Fukuyo, Y.; Ishimaru, T.; Pholpunthin, P.; Wisessang, S.; Saitanu, K.; Panickyakarn, V.; Piyankarnchana, T. Protogonyaulax cohorticula, a toxic dinoflagellate found in the Gulf of Thailand. Toxicon 1988, 26, 709-712.

23. Fukuyo, Y.; Yoshida, K.; Ogata, T.; Ishimaru, T.; Kodama, M.; Pholpunthin, P.; Wisessang, S.; Phanichyakarn, V.; Piyakarnchana, T. Suspected causative dinoflagellates of paralytic shellfish poisoning in the Gulf of Thailand. In Red Tides, Biology, Environmental Science, and Toxicology; Okaichi, T., Anderson, D. M., Nemoto, T., Eds.; Elsevier: New York, 1989; pp. 403-406.

24. White, A.W.; Maranda, L. Paralytic shellfish toxins in the dinoflagellate Gonyaulax excavate and in shellfish. J. Fish. Res. Bd. Can. 1978, 35, 397-402.

25. Anderson, D. M.; Kulis, D. M.; Sullivan, J. J.; Hall, S. Toxin composition in one isolate of the dinoflagellate Alexandrium fundyense. Toxicon 1990, 28, 885-893.

26. Hallegreaff, G. M.; Steffensen, D. A.; Wetherbee, R. Three estuarine Australian dinoflagellates that can produce paralytic shellfish toxins. J. Plankton. Res. 1988, 10, 533-541.

27. Oshima, Y.; Hirota, M.; Yasumoto, T; Hallegraeff, G. M.; Blackburn, S. I; Steffensen, D. A. Production of paralytic shellfish toxins by the dinoflagellate Alexandrium minutum Halim from Australia. Bull. Jap. Soc. Sci. Fish. 1989, 55, 925.

28. Franco, J. M.; Fernandez, P.; Reguera, B. Toxin profiles of natural populations and cultures of Alexandrium minutum Halim and Galician (Spain) coastal waters. J. Appl. Phycol. 1994, 6, 275-279.

29. Mascarenhas, I.; Alvito, P.; Franca, S.; Sousa, I.; Martinez, A. G.; Rodriguez Vasquez, J. A. The dinoflagellate Alexandrium lusitanicum isolated from the coast of Portugal: observations on toxicity and ultrastructure during growth phases. In Harmful Marine Algal Blooms; Lassus, P., Arzul, G., Erard-Le-Dean, E., Gentein, P., Marcaillou- Le-Baut, C., Eds.; Lavoisier: Paris 1995; pp. 71-76. 
30. Lush, G. J.; Halegraeff, G. M. High toxicity of the red tide dinoflagellate Alexandrium minutum to the brine shrimp Artemia salina. In Harmful and Toxic Algal Blooms; Yasumoto, T., Oshima, Y., Fukuyo, Y., Eds.; International Intergovernmental Oceanographic Commission of UNESCO: Paris, 1996; pp. 389-392.

31. Hansen, P. J.; Cembella, A. D.; Moestrup, Ø. The marine dinoflagellate Alexandrium ostenfeldii: paralytic shellfish toxin concentration, composition, and toxicity to a tintinnid ciliate. J. Phycol. 1992, 28, 597-603.

32. Mackenzie, L.; White, D.; Oshima, Y.; Kapa, J. The resting cyst and toxicity of Alexandrium ostenfeldii. Phycologia 1996, 35, 1348-155.

33. Cembella, A. D.; Quilliam, M. A.; Lewis, N. I.; Bauder, A. G.; Wright, J. L. C. Identifying the planktonic origin and distribution of spirolodes in coastal Nova Scotian waters. In Harmful Algae; Reguera, B., Blanco, J., Fernández, M. I., Wyatt, T., Eds.; Xunta de Galicia and IOC: Galicia and Paris, 1998; pp. 481-484.

34. Cembella, A. D.; Lewis, N. I.; Quilliam, M. A. The marine dinoflagellate Alexandrium ostenfeldii (Dinophyceae) as the causative organism of spirolide shellfish toxins. Phycologia 2000, 39, 67-74.

35. Prakash, A. Growth and toxicity of a marine dinoflagellate, Gonyaulax tamarensis. J. Fish. Res. Bd. Can. 1967, 24, 1589-1606.

36. Oshima, Y.; Yasumoto, T. Analysis of toxins in cultured Gonyaulax excavata. In Toxic Dinoflagellate Blooms; Taylor, D. L., Seliger, Eds.; Elsevier: New York, 1979; pp. 377-380.

37. Schantz, E. J. Historical perspective on paralytical shellfish poisoning In Seafood Toxins; Ragelis, E. P., Ed.; American Chemical Society Symposium Series: Washington D.C., 1984; pp. 99-111.

38. Ogata, T.; Kodama, M.; Ishimaru, T. Toxin production in the dinoflagellate Protogonyaulax tamarensis. Toxicon, 1987, 25, 923-928.

39. Cembella, A. D.; Therriault, J.-C.; Beland, P. Toxicity of cultured isolates and natural populations of Protogonyaulax tamarensis from the St. Lawrence Estuary. J. Shellfish Res. 1988, 7, 611-621.

40. Lee, J. S.; Jeon, J.-K.; Han, M.-S.; Oshima, Y.; Yasumoto, T. Paralytic shellfish toxins in the mussel Mytilus edulis and dinoflagellate Alexandrium tamarense from Jinhae Bay, Korea. Bull. Korean Fish. Soc., 1992, 25, 144-150.

41. Oshima, Y.; Sugino, K.; Itakura, H.; Hirota, M; Yasumoto, T. Comparative studies on paralytic shellfish toxin profile of dinoflagellates and bivalves. In Toxic Marine Phytoplankton; Graneli, E., Sundstroem, B., Edler, L., Anderson, D.M., Eds.; Elsevier Press: New York, 1990; pp. 391-396.

42. Wisessang, S.; Ogata, T.; Kodama, M.; Fukuyo, Y.; Ishimaru, T.; Saitanu, K.; Yongvanich, T.; Piyakarnchana. Accumulation of paralytic shellfish toxins by green mussel Perna viridis by feeding on cultured cells of Alexandrium cohorticula isolated from the Gulf of Thailand. Nippon Suis. Gakk. 1991, 57,127-131.

43. Oshima, Y.; Yasumoto, T.; Hallegraeff, G.; Blackburn, S. Paralytic shellfish toxins and causative organisms in the tropical Pacific and Tasmanian waters. In Progress in Venom and 
Toxin Research; Gopalakrishnakone, P., Tans, C. K., Eds; National University of Singapore: Singapore, 1987; pp. 423-428.

44. Oshima, Y.; Blackburn, S. I.; Hallegraeff, G.M. Comparative study on paralytic shellfish toxin profiles of the dinoflagellate Gymnodinium catenatum from three different countries. Mar. Biol. 1993, 116, 471-476.

45. Oshima, Y.; Itakura, H.; Lee, K.-C.; Yasumoto, T.; Blackburn, S.; Hallegraeff, G. Toxin production by the dinoflagellate Gymnodinium catenatum. In Toxic Phytoplankton Blooms in the Sea; Smadya, T. J., Shimizu, Y., Eds.; Elsevier: Amsterdam, 1993; pp. 907-912.

46. Anderson, D. M.; Sullivan, J. J.; Reguera, B. Paralytic shellfish poisoning in north-west Spain: the toxicity of the dinoflagellate Gymnodinium catanatum. Toxicon 1989, 27, 665-674.

47. Maclean, J. L. Red tide and paralytic shellfish poisoning in Papua New Guinea. Papua New Guinea Agric. J. 1973, 24, 131-138.

48. Maclean, J. L. Indo-Pacific red tides. In Toxic Dinoflagellate Blooms; Taylor, D. L., Seliger, S. S., Eds.; Elsevier: New York, 1979; pp. 173-178.

49. Steidinger, K.A.; Tester, L.S.; Taylor, F.J.R. A redescription of Pyrodinium bahamense var. compressa (Böhm) stat. nov. from Pacific red tides. Phycologia 1980, 19, 329-334.

50. Harada, T.; Oshima, Y.; Kamiya, H.; Yasumoto, T. Confirmation of paralytic shellfish toxins in the dinoflagellate Pyrodinium bahamense var. compressa and bivalves in Palau. Nippon Suis. Gakk. 1982, 48, 821-825.

51. Harada, T.; Oshima, Y.; Yasumoto, T. Structures of two paralytic shellfish toxins, gonyautoxins V and VI, isolated from a tropical dinoflagellate, Pyrodinium bahamense var. compressa, Agric. Biol. Chem. 1983, 46, 1861-1864.

52. Oshima, Y.; Kotaki, Y.; Harada, T.; Yasumoto, T. Paralytic shellfish toxins in tropical waters. In Seafood Toxins; Ragelis, E. P., Eds.; American Chemical Society Symposium Series: Washington D.C., 1984; pp. 161-170.

53. Rosales-Loessener, F.; de Porras, E.; Dix, M. W. Toxic shellfish poisoning in Guatemala. In Red Tides, Biology, Environmental Science and Toxicology; Okaichi, T., Anderson, D. M., Nemoto, T., Eds.; Elsevier: New York, 1989; pp. 113-116.

54. Usup, G.; Kulis, D. M.; Anderson, D. M. Growth and toxin production of the toxic dinoflagellate Pyrodinium bahamense var. compressum in laboratory cultures. Nat. Toxins 1994, 2, 35-43.

55. Usup, G.; Kulis, D. M.; Anderson, D. M. Toxin production in a Malaysian isolate of the toxic dinoflagellate Pyrodinium bahamense var. compressum. In Harmful Marine Algal Blooms; Lassus, P., Arzul, G., Erard-Le-Denn, E., Gentein, P., Marciallou-Le-Baut, C., Eds.; Lavoisier: Paris, 1995; pp. 519-524.

56. Orellana-Capeda, E.; Martinez-Romero, E.; Munoz-Cabrera, L.; Lopez-Ramirez, P.; CabreraMancilla, E.; Ramirez-Camarena, C. 1998. Toxicity associated with blooms of Pyrodinium bahamense var. compressum in southwestern Mexico. In Harmful Algae; Reguera, B., Blanco, J., Fernandez, M. L., Wyatt, T., Eds.; Xunta de Galicia and IOC: Galicia and Paris, 1988; p. 60.

57. Badylak, S.; Kelley, K.; Phlips, E. J. A description of Pyrodinium bahamense (Dinophyceae) from the Indian River Lagoon, Florida, USA. Phycologia 2004, 43, 653-657. 
58. Landsberg, J. H.; Hall, S.; Johannessen, J. N.; White, K. D.; Conrad, S. M.; Abbott, J. P.; Flewelling, L. J.; Richardson, R. W.; Dickey, R. W.; Jester, E. L. E.; Etheridge, S. M.; Deeds, J. R.; Van Dolah, F. M.; Leighfield, T. A.; Zou, Y.; Beaudry, C. G.; Benner, R. A.; Rogers, P. L.; Scott, P. S.; Kawabata, K.; Wolny, J. L.; Steidinger, K. A. Saxitoxin puffer fish poisoning in the United States, with the first report of Pyrodinium bahamense as the putative toxin source. Environ. Health Perspect. 2006, 114, 1502-1507.

59. May, V.; McBarron, E. J. Occurrence of the blue-green alga, Anabaena circinalis Rabenh, in New South Wales and toxicity to mice and honey bees. J. Aust. Inst. Agric. Sci. 1973, 39, 264266.

60. McBarron, E. J.; Walker, R. I.; Gardner, I.; Walker, K. H. Toxicity of livestock to the bluegreen alga Anabaena circinalis. Aust. Vet. J. 1975, 51, 587-588.

61. Sivonen, K.; Himberg, K.; Luukkainen, R.; Niemela, S. I.; Poon, G. K.; Codd, G. A. Preliminary characterization of neurotoxic cyanobacterial blooms and strains from Finland. Tox. Assess. Int. J. 1989, 4, 339-352.

62. Kiviranta, J.; Sivonen, K.; Niemala, S. I.; Huovinen, K. Detection of toxicity of cyanobacteria by Artenia salina bioassay. Environ. Toxicol. Water Qual. 1991, 6, 423-436.

63. Humpage, A. R.; Rositano, J.; Breitag, A. H.; Brown, R.; Baler, P. D.; Nicholson, B. C.; Steffensen, D. A. Paralytic shellfish poisons from Australian cyanobacterial blooms. Aust. J. Mar. Freshwat. Res. 1994, 45, 476-471.

64. Negri, A. P.; Jones, G. J. Bioaccumulation of paralytic shellfish poisoning (PSP) toxins from the cyanobacterium Anabaena circinalis by the freshwater mussel Alathyria condola. Toxicon 1995, 33, 667-668.

65. Negri, A. P.; Jones, G. J.; Blackburn, S Paralytic shellfish toxins in Australian strains of the freshwater cyanobacteria Anabaena circinalis. In Harmful Algae; Reguera, B., Blanco, J., Fernandez, M. L., Wyatt, T., Eds.; Xunta de Galicia and IOC: Galicia and Paris, 1998; pp. 345-348.

66. Negri, A. P.; Jones, G. J.; Hindmarch, M. Sheep mortality associated with paralytic shellfish poisoning toxins from the cyanobacterial Anabaena circinalis. Toxicon 1995, 33, 1321-1329.

67. Rapala, J.; Robertson, A.; Negri, A.P.; Berg, K.A.; Tuomi, P.; Lyra, C.; Erkomaa, K.; Lahti, K.; Hoppu, K.; Lepistö, L. First report of saxitoxin in Finnish lakes and possible associated effects on human health. Environ. Toxicol. 2005, 20, 331-340.

68. Pereira, P.; Li, R. H.; Carmichael, W. W.; Dias, E.; Franca, S. Taxonomy and production of paralytic shellfish toxins by the freshwater cyanobacterium Aphanizomenon gracile LMECYA40. Eur. J. Phycol. 2004, 39, 361-368.

69. Jackim, E.; and Gentile, J. Toxins of a blue-green alga: similarity to saxitoxin. Science 1968, 162, 915-916.

70. Sawyer, P. J.; Gentile, J. H.; Sasner Jr., J. J. Demonstration of a toxin from Aphanizomenon flos-aquae (L.). Ralfs. Can. J. Microbiol. 1968, 14, 1199-1204.

71. Gentile, J. H.; Maloney, T. E. Toxicity and environmental requirements of a strain of Aphanizomenon flos-aquae (L.) Ralfs. Can J. Microbiol. 1969, 15, 165-173. 
72. Alam, M.; Shimidzu, Y.; Iwaka, M.; Sasner, J. J. Reinvestigation of the toxins from the bluegreen algae, Aphanizomenon flos-aquae, by a high performance chromatographic method. $J$. Environ. Sci. Hlth. A 1978, 13, 493-499.

73. Ikawa, M.; Wegener, K.; Foxall, T. L.; Sasner Jr., J. J. 1982. Comparison of the toxins of the blue-green alga Aphanizomenon flos-aquae with the Gonyaulax toxins. Toxicon 1982, 20, 747 752.

74. Ikawa, M.; Auger, K.; Mosley, S.; Sasner, J.; Noguchi, T.; Hashimoto, K. Toxin profiles of the blue-green alga Aphanizomenon flos-aquae: In Toxic Dinoflagellates; Anderson, D. M., White, A. W., Baden, D. G., Eds.; Elsevier: New York, 1985; pp. 299-304.

75. Mahmood, N. A.; Carmichael, W.W. Paralytic shellfish poisons produced by the freshwater cyanobacterium Aphanizomenon flos-aquae NH-5. Toxicon 1986, 24, 175-186.

76. Pereira, P.; Onodera, H.; Andrinolo, D.; Franca, S.; Araújo, F.; Lagos, N.; and Oshima, Y. Paralytic shellfish toxins in the freshwater cyanobacterium Aphanizomenon flos-aquae, isolated from Montargil Reservoir, Portugal. Toxicon 2000, 38, 1689-1702.

77. Li, R. H.; Carmichael, W. W.; Pereira, P. Morphological and 16S rRNA gene evidence for reclassification of the paralytic shellfish toxin producing Aphanizomenon flos-aquae LMECYA 31 as Aphanizomenon issatschenkoi (Cyanophyceae). J. Phycol. 2003, 39, 814-818.

78. Lagos, N.; Onodera, H.; Zagatto, P.A.; Azevedo, S.M.; Oshima, Y. The first evidence of paralytic shellfish toxins in the freshwater cyanobacterium Cylindrospermopsis raciborskii, isolated from Brazil. Toxicon 1999, 37, 1359-1373.

79. Molica, R.; Onodera, H.; Garcia, C.; Rivas, M.; Andrinolo, D.; Nascimento, S.; Meguro, H.; Oshima, Y.; Azevedo, S.; Lagos, N. Toxins in the freshwater cyanobacterium Cylindrospermopsis raciborskii (Cyanophyceae) isolated from Tabocas reservoir in Caruaru, Brazil, including demonstration of a new saxitoxin analogue. Phycologia 2002, 41, 606-611.

80. Carmichael, W. W.; Evans, W. R.; Yin, Q. Q.; Bell, P.; Moczydlowski, E. Evidence for paralytic shellfish poisons in the freshwater cyanobacterium Lyngbya wollei (Farlow ex Gomont) comb. Nov. Appl. Environ. Microbiol. 1997, 63, 3104-3110.

81. Onodera, H.; Satake, M.; Oshima, Y.; Yasumoto, T.; Carmichael, W. W. New saxitoxin analogues from the freshwater filamentous cyanobacterium Lyngbya wollei. Nat. Tox. 1997, 5, 146-151.

82. Pomati, F.; Sacchi, S.; Rossetti, C.; Giovannardi, S.; Onodera, H.; Oshima, Y.; Neilan, B.A. The freshwater cyanobacterium Planktothrix sp. FP1: molecular identification and detection of paralytic shellfish poisoning toxins. J. Phycol. 2000, 36, 553-562.

83. Bravo, I.; Cacho, E.; Franco, J. M.; Miguez, A.; Reyero, M .I.; Martinez, A. Study of PSP toxicity in Haliotis tuberculata from the Galician coast. In Harmful and Toxic Algal Blooms; Yasumoto, T., Oshima, Y., Fukuyo, Y., Eds.; Intergovernmental Oceanographic Commission of UNESCO: Paris, 1996; pp. 421-424.

84. Shumway, S. E. A review of the effects of algal blooms on shellfish and aquaculture. J. World Aquacult. Soc. 1990, 21, 65-104.

85. Shumway, S. E. Phycotoxin-related shellfish poisoning: bivalve molluscs are not the only vectors. Rev. Fish. Sci. 1995, 3, 1-31. 
86. Pereira, P.; Dias, E.; Franca, S.; Pereira, E.; Carolino, M.; Vasconcelos, V. Accumulation and depuration of cyanobacterial paralytic shellfish toxins by the freshwater mussel Anodonata cygnea. Aquatic Toxicol. 2004, 68, 339-350.

87. Anderson, D. M. Toxin variability in Alexandrium species. In Toxic marine phytoplankton. Graneli, E., Sundstroem, B., Edler, L., Anderson, D. M., Eds.; Elsevier Press: New York, 1990; pp. 41-51.

88. Anderson, D. M.; Kulis, D. M.; Doucette, G. J.; Gallagher, J.C.; Balech, E. Biogeography of toxic dinoflagellates in the genus Alexandrium from the northeastern United States and Canada. Mar. Biol. 1994, 120, 467-478.

89. Landsberg, J. H. Neoplasia and biotoxins in bivalves: is there a connection? J. Shellfish. Res. 1996, 15, 205-233.

90. Landsberg, J. H. The effects of harmful algal blooms on aquatic organisms. Rev. Fish. Sci. 2002, 10, 113-390.

91. Sakamoto, S.; Ogata, T.; Sato, S.; Kodama, M.; Takeuchi, T. Causative organism of paralytic shellfish toxins other than toxic dinoflagellates. Mar. Ecol .Prog. Ser. 1992, 89, 229-235.

92. Doucette, G. J.; Kodama, M.; Franca, S.; Gallacher, S. Bacterial interactions with harmful algal bloom species: bloom ecology, toxigenesis, and cytology. In Physiological Ecology of Harmful Algal Blooms; Anderson, D. M., Cembella, A. D., Hallegraeff, G. M., Eds.; Springer-Verlag: Heidelberg, 1998; pp. 619-647.

93. Kodama, M.; Ogata, T.; Sakamoto, S.; Sato, S.; Honda, T.; Miwatani, T. Production of paralytic shellfish toxins by a bacterium Moraxella sp. isolated from Protogonyaulax tamarensis. Toxicon 1990, 28, 707-714.

94. Kodama, M.; Ogata, T.; Sato, S.; Sakamoto, S. Possible association of marine bacteria with paralytic shellfish toxicity in bivalves. Mar. Ecol. Prog. Ser, 1990, 61, 203-206.

95. Kodama, M.; Doucette, G. J.; Green, D. H. Relationships between bacteria and harmful algae In Ecology of Harmful Algae; Springer-Verlag: Berlin, 2006; pp. 243-255.

96. Ogata, T.; Pholpunthin, P.; Kukuyo, Y.; Kodama, M. Occurrence of Alexandrium cohorticula in Japanese coastal water. J. Appl. Phycol. 1990, 2, 351-356.

97. Silva, E. S. Intracellular bacteria: the origin of dinoflagellate toxicity. J. Environ. Pathol. Toxicol. Oncol. 1990, 10, 124-128.

98. Catterall, W.A. The voltage-sensitive sodium channel: a receptor for multiple toxins. In Toxic Dinoflagellates; Anderson, D. M., White, A.W., Baden, D.G., Eds.; Elsevier: New York, 1985; pp 329-342.

99. Kao, C. Y. Paralytic shellfish poisoning. In Algal Toxins in Seafood and Drinking Water; Falconer, I. R., Ed.; Academic Press: London, 1993; pp 75-86.

100. Adnan, Q. Distribution of dinoflagellates at Jakarta Bay, Taman Jaya, Banten, and Benoa Bay, Bali: A report of an incident of fish poisoning at eastern Nusa Tenggara. In Consult. Meet. on Toxic Red Tides and Shellfish Toxicity in Southeast Asia; White, A.W., Anraku, M., Hooi, K-K., Eds.; Singapore, 11-14 September, 1984; pp. 25-27.

101. Shumway, S. E.; Barter, J.; Sherman-Caswell, S. Auditing the impact of toxic algal blooms on oysters. Environ. Audit. 1990, 2, 41-56. 
102. Shumway, S. E.; Cembella, A. D. The impact of toxic algae on scallop culture and fisheries. Rev. Fish. Sci. 1993, 1, 121-150.

103. Bricelj, V. M.; Shumway, S. E. An overview of the occurrence and transfer kinetics of paralytic shellfish toxins in bivalve molluscs. In Harmful and Toxic Algal Blooms. Proceedings of the Seventh International Conference on Toxic Phytoplankton, Sendai, Japan, 12-16 July, 1995; Yasumoto, T., Oshima, Y., Fukuyo, Y., Eds.; IOC of UNESCO: Paris, 1998; pp. 431 436.

104. Bricelj, V. M.; Shumway, S. E. Paralytic shellfish toxins in bivalve molluscs: occurrence, transfer kinetics, and biotransformation. Rev. Fish. Sci. 1998, 6, 315-383.

105. Schantz, E. J.; Mold, J. D.; Stanger, D. W.; Shavel, J.; Riel, J.; Bowden, J. P.; Lynch, R. S.; Whyler, B.; Reigel, B.; Sommer, H. Paralytic shellfish poison. VI. A procedure for the isolation and purification of the poison from toxic clams and mussel tissues. J. Am. Chem. Soc. 1957, 78, 5230-5235.

106. Schantz, E. J. Biochemical studies of paralytic shellfish poisons. Ann. N.Y. Acad. Sci. 1960, 89, 843-855.

107. Twarog, B. M.; Yamaguchi, H. Resistance to paralytic shellfish toxins in bivalve molluscs. In Proc. First Int. Conf. Toxic Dinoflagellate Blooms; LoCicero, V. R., Ed.; Massachusetts Science and Technology Foundation: Wakefield, MA. 1975; pp. 381-393.

108. Hartwell, A. D. Hydrographic factors affecting the distribution and movement of toxic dinoflagellates in the western Gulf of Maine. In Proc. First Int. Conf. Toxic Dinoflagellate Blooms; LoCicero V. R., Ed.; Massachusetts Science and Technology Foundation: Wakefield, MA, 1975; pp. 47-68.

109. Shumway, S. E.; Sherman, S. A.; Cembella A. D.; Selvin, R. Accumulation of paralytic shellfish toxins by surfclams, Spisula solidissima (Dillwyn, 1897) in the Gulf of Maine: seasonal changes, distribution between tissues, and notes on feeding habits. Nat. Toxins 1994, 2, 236-251.

110. Bricelj, V. M.; Cembella, A.D. Fate of gonyautoxins in surfclams, Spisula solidissima, grazing upon toxigenic Alexandrium. In Harmful Marine Algal Blooms; Lassus, P., Arzul, G., ErardLe-Denn, E., Gentien, P., Marcaillou-Le-Baut, C., Eds.; Technique et Documentation, Lavoisier: Paris, 1995; pp. 413-418.

111. Cembella, A. D.; Shumway, S.E. Anatomical and spatio-temporal variation in PSP toxin composition in natural populations of the surf clam Spisula solidissima in the Gulf of Maine. In Harmful Marine Algal Blooms. Lassus, P., Arzul, G., Erard-Le-Denn, E., Gentien, P., Marcaillou-Le-Baut, C., Eds.; Technique et Documentation, Lavoisier: Paris, 1995; pp. 421-426.

112. Lassus, P.; Wildish, D. J.; Bardouil, M.; Martin, J. L.; Bohec, M.; Bougrier, S. Ecophysiological study of toxic Alexandrium spp. effects on the oyster Crassostrea gigas. In Harmful and Toxic Algal Blooms. Proceedings of the Seventh International Conference on Toxic Phytoplankton, Sendai, Japan, 12-16 July, 1995; Yasumoto, T., Oshima, Y., Fukuyo, Y., Eds.; IOC of UNESCO: Paris, 1996; pp. 409-412. 
113. Curtis, K. M.; Trainer, V.L.; Shumway, S.E. Paralytic shellfish toxins in geoduck clams (Panope abrupta): variability, anatomical distribution, and comparison of two toxin detection methods. J. Shellfish Res. 2000, 19, 313-319.

114. Smith, E. A.; Grant, F.; Ferguson, C. M.; Gallacher, S. Biotransformations of paralytic shellfish toxins by bacteria isolated from bivalve mollusks. Appl. Environ. Microbiol. 2001, 67, 23452353.

115. Li, A. M.Y.; Yu, P. K.N.; Hsieh, D.P.H.; Wang, W.-X.; Wu, R. S. S.; Lam, P. K. S. Uptake and depuration of paralytic shellfish toxins in the greenlipped mussel, Perna viridis: a dynamic model. Environ. Toxicol. Chem. 2005, 24, 129-135.

116. Twarog, B.; Hidaka, T.; Yamaguchi, H. Resistance to tetrodotoxin and saxitoxin in nerves of bivalve mollusks. Toxicon 1972, 10, 273-278.

117. Bricelj, V. M.; Cembella, A.D.; Laby, D.; Shumway, S.E.; Cucci, C.L. Comparative physiological and behavioral responses to PSP toxins in two bivalve molluscs, the softshell clam, Mya arenaria, and surfclam, Spisula solidissima. In Harmful and Toxic Algal Blooms. Proceedings of the Seventh International Conference on Toxic Phytoplankton, Sendai, Japan, 12-16 July, 1995; Yasumoto, T., Oshima, Y., Fukuyo, Y., Eds.; IOC of UNESCO: Paris, 1996; pp. 405-404.

118. Bricelj, V. M.; Greene, M.; Cembella, A. D. Growth of the blue mussel Mytilus edulis on toxic Alexandrium fundyense and effects of gut passage on dinoflagellate cells. In Toxic Phytoplankton Blooms in the Sea; Smayda, T. J., Shimuzu, Y., Eds.; Elsevier Press: Amsterdam, 1993; pp. 371-376

119. Bricelj, V. M.; Connell, L.; Konoki, K.; Macquarrie, S. P.; Scheuer, T.; Catterall, W. A.; Trainer, V. L. Sodium channel mutation leading to saxitoxin resistance in clams increases risk of PSP. Nature 2005, 434(7034), 763-767.

120. Beitler, M. K.; Liston, J. Uptake and distribution of PSP toxins in butter clams. In Toxic Marine Phytoplankton; Graneli, E., Sundstrom, B., Edler, L., Anderson, D. M., Eds.; Elsevier Press: New York, 1990; pp. 257-262.

121. Martin, J. L.; White, A. W.; Sullivan, J. J. Anatomical distribution of paralytic shellfish toxins in softshell clams. In Toxic Marine Phytoplankton; Graneli, E., Sundstroem, B., Edler, L., Anderson, D. M., Eds.; Elsevier Press: New York, 1990; pp. 379-384.

122. Cembella, A. D.; Shumway, S.E.; Larocque, R. Sequestering and putative biotransformation of paralytic shellfish toxins by the sea scallop Placopecten magellanicus: Seasonal and spatial scales in natural populations. J. Exp. Mar. Biol. Ecol. 1994, 180, 1-22.

123. Jamieson, G. S.; Chandler, R. A. Paralytic shellfish poison in sea scallops (Placopecten magellanicus) in the west Atlantic. Can. J. Fish. Aquat. Sci. 1983, 40, 313-318.

124 Sullivan, J. J.; Iwaoka, W.T.; Liston, J. Enzymatic transformation of PSP toxins in the littleneck clam (Protothaca staminaea). Biochem. Biophys. Res. Commun. 1983, 114, 465-472.

125. Robertson, A.; Stirling, D.; Robillot, C.; Llewellyn, L.; Negri, A. First report of saxitoxin in octopi. Toxicon 2004, 44, 765-771.

126. Daigo, K.; Noguchi, T.; Miwa, A.; Kawai, N.; Hashimoto, K. Resistance of nerves from certain toxic crabs to paralytic shellfish poison and tetrodotoxin. Toxicon 1988, 26, 485-490. 
127. Nagashima, Y.; Ohgoe, H.; Yamamoto, K.; Shimakura, K.; Shomi, K. Resistance of non-toxic crabs to paralytic shellfish poisoning toxins. In Harmful Algae; Reguera, B., Blanco, J., Fernandez, M. L., Wyatt, T., Eds.; Xunta de Galicia and Intergovernmental Oceanographic Commission of UNESCO: Grafisant, Santiago de Compostela, Spain, 1998; pp. 604-606.

128. Choi, M.-C.; Yu, P.K.N.; Hsieh, D.P.H., Lam, P.K.S. Trophic transfer of paralytic shellfish toxins from clams (Ruditapes philippinarum) to gastropods (Nassarius festivus). Chemosphere, 2006, 64, 1642-1649.

129. Quayle, D. B. Paralytic shellfish poisoning in eastern Canada. Bull. Fish. Res. Bd. Can. 168. Fisheries Research Board of Canada: Ottawa, Canada. 1971.

130. Tufts, N. R. Molluscan transvectors of paralytic shellfish poisoning In Toxic Dinoflagellate Blooms; Taylor, D. L., Seliger, H.H., Eds.; Elsevier: New York, 1979; pp. 403-408.

131. Prakash, A.; Medcof, J. C.; Tennant, A. D. Paralytic shellfish poisoning in Eastern Canada. Fish. Res. Bd. Can. 1971, Bull. No. 177, 87.

132. White, A.W.; Nassif, J.; Shumway, S. E.; Whitaker, D. K. Recent occurrence of paralytic shellfish toxins in offshore shellfish in the northeastern United States. In Toxic Phytoplankton Blooms in the Sea; Smayda, T. J., Shimuzu, Y., Eds.; Elsevier: Amsterdam, 1993; pp. 435-440.

133. Worms, J.; Bouchard, N.; Cormier, R.; Pauley, K. E.; Smith, J. C. New occurrences of paralytic shellfish poisoning toxins in the southern Gulf of St. Lawrence, Canada. In Toxic Phytoplankton Blooms in the Sea; Smayda, T. J., Shimizu, Y., Eds.; Elsevier: Amsterdam, 1993; pp. 353-358.

134. Carreto, J. I.; Elbusto, C.; Sancho, H.; Carignan, M.; Yasumoto, T.; Oshima, Y. Comparative studies on paralytic shellfish toxin profiles of marine snails, mussels and an Alexandrium tamarense isolate from the Mar del Plata coast (Argentina). Rev. Invest, Des. Pesq. 1996, 10, 101-107.

135. Ito, K.; Asakawa, M.; Beppu, R.; Takayama, H.; Miyazawa, K. PSP-toxicification of the carnivorous gastropod Rapana venosa inhabiting the estuary of Nikoh River, Hiroshima Bay, Hiroshima Prefecture, Japan. Mar. Poll. Bull. 2004, 48, 1116-1121.

136. Sang, J. W. T.; Ming, T. T. Red tide and paralytic shellfish poisoning in Sabah, Malaysia. In Consult. Meet. on Toxic Red Tides and Shellfish Toxicity in Southeast Asia, White, A. W., Anraku, M., Hooi, K.-K., Eds.; Singapore, 11-14 September, 1984, pp. 35-42.

137. Ming, T. T.; Wong T-S. J. Summary of red tide and paralytic shellfish poisoning in Sabah. In Biology, Epidemiology and Management of Pyrodinium red tides; Hallegraeff, G. M., MacLean, J. L., Eds., Bandar Seri Begawan: Darussalam, Brunei, 1989; pp. 19-26.

138. Kan, S. K.; Singh, N.; Chan, M. K. Oliva vidua fulminans, a marine mollusc, responsible for five fatal cases of neurotoxic food poisoning in Sabah, Malaysia. Trans. R. Soc. Trop. Med. Hyg. 1986, 80, 64-65.

139. Jaafar, M. H.; Subramaniam, S. Occurrences of red tide in Brunei Darussalam and methods of monitoring and surveillance. In Toxic Red Tides and Shellfish Toxicity in Southeast Asia; White, A.W., Anraku, M., Hooi, K-K., Eds.; Southeast Asian Fisheries Development Center and the International Development Research Center: Singapore, 1984; pp. 17-24.

140. Jaafar, M. H.; de Silva, M. W. R. N.; Sharifuddin, P. H. Y. Pyrodinium red tide occurrences in Brunei Darussalam. In Biology, Epidemiology and Management of Pyrodinium Red Tides; 
Hallegraeff, G.M.; MacLean, J.L., Eds.; Bandar Seri Begawan, Brunei: Darussalam, 1989; pp. 9-17.

141. Li, Y.; Jia, X. ; Yang, M.; Zhong, Y.; Quan, G.; Fan, P. Paralytic shellfish poison in contaminated shellfish along coast of China. Trop. Oceanol. 1999, 19, 90-96.

142. Li, Y.; Chen, S. Report of 8 incidents of intoxication due to Nassarius (Zeuxis) succinctus. Chin. J. Surg. 1981, 20, 231-232.

143. Nagashima, Y.; Arakawa, O.; Shiomi, K.; Noguchi, T. Paralytic shellfish toxins in a trumpet shell, Charonia lampas, from Spain In Harmful and Toxic Algal Blooms; Yasumoto, T., Oshima, Y., Fukuyo, Y., Eds.; Intergovernmental Oceanic Commission of UNESCO, Japan: Sendai, 1996; pp. 425-427.

144. Liao, H. J.; Hwang, D.F. Survey of paralytic toxins in shellfish in southern Taiwan between 1995 and 1997. J. Nat. Toxins 2000, 9, 63-71.

145. Hwang, D. F.; Cheng, C. A.; Jeng, S. S. Gonyautoxin-3 as a minor toxin in the gastropod Niotha clathrata in Taiwan. Toxicon 1994, 32, 1573-1579.

146. Sato, S.; Ogata, T.; Kodama, M. Wide distribution of toxins with sodium channel blocking activity similar to tetrodotoxin and paralytic shellfish toxins in marine animals. In Toxic Phytoplankton Blooms in the Sea; Smayda, T. J., Shimizu, Y., Eds.; Elsevier: Amsterdam, 1993; pp. 429-434.

147. Negri, A.; Llewellyn, L. Comparative analyses by HPLC and the sodium channel and saxiphilin 3H-saxitoxin receptor assays for paralytic shellfish toxins in crustaceans and molluscs from tropical North West Australia. Toxicon 1998, 36, 283-298.

148. Martinez, A.; Franco, J. M.; Bravo, I.; Mazoy, M.; Cacho, E. PSP toxicity in Haliotis tuberculata from NW Spain. In Toxic Phytoplankton Blooms in the Sea; Smayda, T. J., Shimizu, Y., Eds., Elsevier: Amsterdam, 1993; pp. 419-423.

149. Bravo, I.; Reyero, M. I.; Cacho, E.; Franco, J. M. Paralytic shellfish poisoning in Haliotis tuberculata from the Galician coast: geographical distribution, toxicity by lengths and parts of the mollusc. Aquat. Toxicol. 1999, 46, 79-85.

150. Pitcher, G. C.; Franco, J. M.; Doucette, G. J.; Powell, C. L.; Mouton, A. Paralytic shellfish poisoning in the abalone Haliotis midae on the west coast of South Africa. J. Shellfish Res. 2001, 20, 895-904.

151. Bravo, I.; Franco, J.M.; Alonso, A.; Dietrich, R.; Molist, P. Cytological study and immunohistochemical location of PSP toxins in foot skin of the ormer, Haliotis tuberculata, from the Galician coast (NW Spain). Mar. Biol. 2001, 138, 709-715.

152. Huchette, S. M. H.; Clavier, J. Status of the ormer (Haliotis tuberculata L.) industry in Europe. J. Shellfish Res. 2004, 23(4), 951-955.

153. Ruiz Sebastián, C.; Etheridge, S.M.; Cook, P.A.; O’Ryan, C.; Pitcher, G. C. Phylogenetic analysis of toxic Alexandrium (Dinophyceae) isolates from South Africa: Implications for the global phylogeography of the Alexandrium tamarense species complex. Phycologia 2005, 44, 49-60.

154. Etheridge, S. M.; Pitcher, G.C.; Roesler, C.S. Depuration and transformation of PSP toxins in the South African abalone Haliotis midae. In Harmful Algae 2002; Steidinger, K. A., Landsberg, J. H., Thomas, C.R., Vargo, G.A., Eds.; Florida Fish and Wildlife Conservation 
Commission, Florida Institute of Oceanography, and Intergovernmental Oceanographic Commission of UNESCO, 2004; pp. 175-177.

155. Anderson, D. M.; Kaefer, B. A.; McGillicuddy Jr., D. J.; Mickelson, M. J.; Keay, K. E.; Libby, P. S.; Manning, J. P.; Mayo, C. A.; Wittaker, D. K.; Hickey, J. M.; He, R.; Lynch, D. R., Smith, K. W. 2005. Initial observations of the 2005 Alexandrium fundyense bloom in southern New England: General patterns and mechanisms. Deep Sea Research Part II: Topical Studies on Oceanography. 2005, 52, 2856-2879.

156. Yasumoto, T.; Oshima, Y.; Konta, T. Analysis of paralytic shellfish toxins of xanthid crabs in Okinawa. Bull. Jap. Soc. Sci. Fish. 1981, 47, 957-959.

157. Arakawa, O.; Noguchi, T.; Shida, Y.; Onoue, Y. 1994. Occurrence of carbamoyl-N-hydroxy derivatives of saxitoxin and neosaxitoxin in a xanthid crab Zosimus aeneus. Toxicon 1994, 32, 175-183.

158. Arakawa, O.; Nishio, S.; Noguchi, T.; Shida, Y.; Onoue, Y. A new saxitoxin analogue from a Xanthid crab Atergatis floridus. Toxicon 1995, 33, 1577-1584.

159. Arakawa, O.; Noguchi, T.; Onoue, Y. Paralytic shellfish toxin profiles of xanthid crabs Zosimus aeneus and Atergatis floridus collected on reefs of Ishigaki Island. Fish. Sci. 1995, 61, 659-662.

160. Kotaki, Y.; Tajiri, Y.; Oshima, Y.; Yasumoto, T. Identification of a calcareous red alga as the primary source of paralytic shellfish toxins in coral reef crabs and gastropods. Bull. Jap. Soc. Sci. Fish. 1983, 49, 283-286.

161. Jonas-Davies, J. and Liston, J. The occurrence of PSP toxins in intertidal organisms. In Toxic dinoflagellates; Anderson, D.M., White, A. W., Baden, D. G., Eds.; Elsevier: New York, 1985; pp. 467-472.

162. Desbiens, M.; Cembella, A. D. Occurrence and elimination kinetics of PSP toxins in the American lobster (Homarus americanus). In Harmful Marine Algal Blooms, Lassus, P., Arzul, G., Erard-Le-Denn, E., Gentien, P., Marcaillou-Le-Baut, C., Eds.; Technique et Documentation, Lavoisier: Paris, 1995; pp. 433-438.

163. Oikawa, H.; Fujita, T.; Satomi, M.; Suzuki, T.; Kotana, Y.; Yano, Y. Accumulation of paralytic shellfish poisoning toxins in the edible shore crab Telmessus acutidens. Toxicon 2002, 40, 1593-1599.

164. Oikawa, H.; Fujita, T.; Saito, K.; Satomi, M.; Yano, Y. Difference in the level of paralytic shellfish poisoning toxin accumulation between the crabs Telmessus acutidens and Charydbis japonica collected in Onahama, Fukushima Prefecture. Fish. Sci. 2007, 73, 395-403.

165. Raj, U.; Haq, U.; Oshima, T.; Yasumoto, T. The occurrence of paralytic shellfish toxins in two species of xanthid crab from Suva Barrier Reef, Fiji Islands. Toxicon 1983, 21, 547-551.

166. Tsai, Y. H.; Hwang, D. F.; Chai, T. J.; Jeng, S.S. Toxicity and toxic components of two xanthid crabs, Atergatis floridus and Demania reynaudi. Toxicon 1997, 35, 1327-1335.

167. Tsai, Y. H.; Hwang, D. F.; Chai, T.J.; Jeng, S. S. Occurrence of paralytic toxin in Taiwanese crab Atergatopsis germaini. Toxicon 1996, 34, 467-474.

168. Llewellyn, L.E.; Endean, R. Toxins extracted from Australian specimens of the crab, Eriphia sebana (Xanthidae). Toxicon 1989, 27, 579-586. 
169. Llewellyn, L. E.; Endean, R. Toxicity and paralytic shellfish toxin profiles of the xanthid crabs, Lophozozymus pictor and Zosimus aeneus, collected from some Australian coral reefs. Toxicon 1989, 27, 596-600.

170. Tsai Y. H.; Hwang, D. F.; Chai, T. J.; Jeng S. S. Occurrence of tetrodotoxin and paralytic shellfish poison in the Taiwanese crab Lophozozymus pictor. Toxicon 1995, 33, 1669-1673.

171. Ho, P. H.; Tsai, Y. -H.; Hwang, C. -C.; Hwang, P. -A.; Hwang, J. -H.; Hwang, D. -F. Paralytic toxins in four species of coral reef crabs from Kenting National Park in southern Taiwan. Food Control 2006, 17, 439-445.

172. Llewellyn, L. E.; Dodd, M. J.; Robertson, A.; Ericson, G.; de Koning, C.; Negri, A.P. Postmortem analysis of samples from a human victim of a fatal poisoning caused by the xanthid crab, Zosimus aenus. Toxicon 2002, 40, 1463-1469.

173. Yasumura, D.; Oshima, Y.; Yasumoto, T.; Alcala, A.C.; Alcala, L.C. Tetrodotoxin and paralytic shellfish toxins in Philippine crabs. Agric. Biol. Chem. 1986, 50, 593-598.

174. Fusetani, N.; Endo, H.; Hashimoto, K.; Takahashi, K. Occurrence of potent toxins in the horseshoe crab Carcinoscorpius rotundicauda. Toxicon 1982, 20, 662-664.

175. Jiang, T. J.; Niu, T.; Xu, Y.X. Transfer and metabolism of paralytic shellfish poisoning from scallop (Chlamys nobilis) to spiny lobster (Panulirus stimpsoni). Toxicon 2006, 48, 988-994.

176. Koyama, K.; Noguchi, T.; Ueda, Y.; Hashimoto, K. Occurrence of neosaxitoxin and other paralytic shellfish poisons in toxic crabs belonging to the family Xanthidae. Nippon. Suis. Gakk. 1981, 47, 965.

177. Llewellyn, L. E. Haemolymph protein in xanthid crabs: its selective binding of saxitoxin and possible role in toxin bioaccumulation. Mar. Biol. 1997, 128, 599-606.

178. Koyama, K.; Noguchi, T.; Uzu, A.; and Hashimoto; K. Individual, local, and size-dependent variations in toxicity of the xanthid crab Zosimus aeneus. Nippon Suis. Gakk. 1983, 49, $1273-$ 1279.

179. Arakawa, O.; Noguchi, T.; Onoue, Y. Transformation of gonyautoxins in the xanthid crab Atergatis floridus. Fish. Sci. 1998, 64, 334-337.

180. Alacala, A.; Alacala, L.; Garth, J.; Yasumura, D.; Yasumoto, T. Human fatality due to ingestion of the crab Demania reynaudii that contained a palytoxin-like toxin. Toxicon 1988, 26, 105-107.

181. Lau, C.; Tan, C.; Li, Q.; Ng, F.; Tuen, R.; Khoo, H. Bioactivity and mechanism of action of Lophozozymus pictor toxin. Toxicon 1995, 33, 901-908.

182. Nocuchi, T.; Uzu, A.; Koyama, K.; Maruyama, J.; Nagashima, Y.; Hashimyo, K. Occurrence of tetrodotoxin as the major toxin in a xanthid crab Atergatis floridus. Nippon Suis. Gakk. 1983, 49, 1887-1892.

183. Oikawa, H.; Fujita, T.; Saito, K.; Watabe, S.; Yano, Y. Comparison of paralytic shellfish toxin between carnivorous crabs (Telmessus acutidens and Charybdis japonica) and their prey mussel (Mytilus galloprovincialis) in an inshore food chain. Toxicon 2004, 43, 713-719.

184. Oikawa, H.; Satomi, M.; Watabe, S.; Yano, Y. Accumulation and depuration rates of paralytic shellfish poisoning toxins in the shore crab Telmessus acutidens by feeding toxic mussels under laboratory controlled conditions. Toxicon 2005, 45, 163-169. 
185. Gessner, B. D.; Middaugh, J. P. Paralytic shellfish poisoning in Alaska: A 20-year retrospective analysis. Am. J. Epidem. 1995, 141, 766-770.

186. Asakawa, M.; Nishimura, F.; Miyazawa, K.; Noguchi, T. 1997. Occurrence of paralytic shellfish poisons in the starfish, Asterias amurensis in Kure Bay, Hiroshima Prefecture, Japan. Toxicon 1997, 35, 1081-1087.

187. Lin, S. -J.; Tsai, Y. -H.; Lin, H. P.; Hwang, D. -F. Paralytic toxins in Taiwanese starfish Astropecten scoparius. Toxicon 1998, 36, 799-803.

188. White, A.W. Dinoflagellate toxins in phytoplankton and zooplankton fractions during a bloom of Gonyaulax excavata. In Toxic Dinoflagellate Blooms; Taylor, D. L., Seliger, H. H., Eds.; Elsevier: New York, 1979; pp. 381-384.

189. White, A.W. Marine zooplankton can accumulate and retain dinoflagellate toxins and cause fish kills. Limnol. Oceanogr. 1981, 26, 103-109.

190. Turiff, N.; Runge, J. A.; Cembella, A. D. Toxin accumulation and feeding behavior of the planktonic copepod Calanus finmarchicus exposed to the red-tide dinoflagellate Alexandrium excavatum. Mar. Biol. 1995, 123, 55-64.

191. Teegarden, G. J.; Cembella, A. D. Grazing of toxic dinoflagellates, Alexandrium spp., by adult copepods of coastal Maine: implications for the fate of paralytic shellfish toxins in marine food webs. J. Exp. Mar. Biol. Ecol. 1996, 196, 145-176.

192. Teegarden, G. J; Cembella, A. D. Grazing of toxic dinoflagellates, (Alexandrium spp.) by estuarine copepods: particle selection of PSP toxins in marine food webs. In Harmful and Toxic Algal Blooms. Proceedings of the Seventh International Conference on Toxic Phytoplankton, Sendai, Japan, 12-16 July, 1995, Yasumoto, T., Oshima, Y., Fukuyo, Y., Eds.; IOC of UNESCO: Paris, 1996; pp. 393-396.

193. Turner, J. Y.; Doucette, G. J.; Powell, C.L.; Kulis, D.M.; Keafer, B.A.; Anderson, D. M. Accumulation of red tide toxins in larger size fractions of zooplankton assemblages from Massachusetts Bay, USA. Mar. Ecol. Prog. Ser. 2000, 203, 95-107.

194. Haya, K.; Martin, J. L.; Waiwood, B. A.; Burridge, L. E.; Hungerford, J. M.; Zitko, V. Identification of paralytic shellfish toxins in mackerel from southwest Bay of Fundy, Canada. In Toxic Marine Phytoplankton; Graneli, E., Sundstrom, B., Edler, L., Anderson, D. M., Eds.; Elsevier Press: New York, 1990; pp. 350-355.

195. Castonguay, M.; Levasseur, M.; Beaulieu, J.- L.; Gregoire, F.; Michaud, S.; Bonneau, E.; Bates, S. S. Accumulation of PSP toxins in Atlantic mackerel: seasonal and ontogenetic variations. J. Fish. Biol., 1997, 50, 1203-1213.

196. Montoya, N. G.; Akselman, R.; Pajaro, M.; Perrotta, R. G.; Franco, J.; Carreto, J.I. Mortandad de caballa (Scomber japonicus) en la plataforma bonarense (Mar Argentino) asociada a un florecimento del dinoflagelado toxico Alexandrium tamarense. Rev. Invest. Des. Pesq. 1997, 11, 145-152.

197. Nakashima, K.; Arakawa, O.; Taniyama, S.; Nonaka, M.; Takatani, T.; Yamamori, K.; Fuchi, Y.; Noguchi, T. 2004. Occurrence of saxitoxins as a major toxin in the ovary of a marine puffer Arothron firmamentum. Toxicon 2004, 43, 207-212. 
198. Sato, S.; Ogata, T.; Borja, V.; Gonzales, C.; Fukuyo, Y.; Kodama, M. Frequent occurrence of paralytic shellfish poisoning toxins as dominant toxins in marine puffer from tropical water. Toxicon 2000, 38, 1101-1109.

199. Zaman, L.; Arakawa, O.; Shimosu, A.; Onoue, Y. Occurrence of paralytic shellfish poison in Bangladeshi freshwater puffers. Toxicon 1997, 235, 423-431.

200. Oliveira, J. S.; Fernandes, S. C. R.; Schwartz, J. A. T.; Pires Jr., O. R.; de Freitas, J.C. Toxicity and toxin identification in Colomesus asellus, an Amazonian (Brazil) freshwater puffer fish. Toxicon 2006, 48, 55-63.

201. Kodama, M.; Ogata, T.; Kawamukai, K.; Oshima, Y.; Yasumoto, T. Occurrence of saxitoxin and other toxins in the liver of pufferfish Takifugu pardalis. Toxicon 1983, 21, 897-900.

202. Nakamura, M.; Oshima, Y.; Yasumoto, T. Occurrence of saxitoxin in puffer fish. Toxicon 1984, 22, 381-385.

203. Ahmed, M. S.; Jaime, E.; Reichelt, M.; Luckas, B. Paralytic shellfish poisoning in freshwater puffer fish (Tetraodon cutcutia) from the River Burigonga, Bangladesh. In Harmful Algal Blooms 2000; Hallegraeff, G.M., Blackburn, S.I., Bolch, C.J., Lewis, R. J., Eds., Intergovernmental Oceanographic Commission of UNESCO: Paris, France, 2001; pp. 19-21.

204. Sato, S.; Kodama, M.; Ogata, T.; Saitanu, K.; Furuya, M.; Hirayama, K.; Kakinuma, K. Saxitoxin as a toxic principle of a freshwater puffer, Tetraodon fangi, in Thailand. Toxicon 1997, 35, 137-140.

205. Kungsuwan, A.; Arakawa, O.; Promset, M.; Onoue, Y. Occurrence of paralytic shellfish poisons in Thai freshwater puffers. Toxicon 1997, 35, 1341-1346.

206. Ngy, L.; Tada, K.; Yu, C.-F.; Takatani, T.; Arakawa, O. Occurrence of paralytic shellfish toxins in Cambodian Mekong pufferfish Tetraodon turgidus: Selective toxin accumulation in the skin. Toxicon 2008, 51, 280-288.

207. White, A.W. Recurrence of kills of Atlantic herring (Clupea harengus harengus) caused by dinoflagellate toxins transferred through herbivorous zooplankton. Can. J. Fish. Aquat. Sci. 1980, 37, 2262-2265.

208. White, A.W. Paralytic shellfish toxins and finfish. In Seafood Toxins; Ragelis, E. P., Ed.; ACS Symposium Series 262, 1984; pp. 171-180.

209. Kwong, R. W. M.; Wang, W. X.; Lam, P. K. S.; Yu, P. K. N.. The uptake, distribution and elimination of paralytic shellfish toxins in mussels and fish exposed to toxic dinoflagellates. Aquat. Toxicol. 2006, 80, 82-91.

210. Jiang, T. -J.; Wang, D. -Z.; Niu, T; Xu, Y. X. Trophic transfer of paralytic shellfish toxins from the cladoceran (Moina mongolica) to larvae of the fish (Sciaenops ocellatus). Toxicon 2007, 50, 639-645.

211. Maclean, J. L.; White, A.W. Toxic dinoflagellate blooms in Asia: A growing concern. In Toxic dinoflagellates; Anderson, D. M., White, A. W., Baden, D. G., Eds.; Elsevier: New York, 1985; pp. 517-520.

212. Gonzalez, C. L.; Ordonez, J. A.; Maala, A. M. Red tide: the Philippine experience. In Red Tides, Biology, Environmental Science and Toxicology; Okaichi, T., Anderson, D.M., Nemoto, T., Eds.; Elsevier: New York, 1989; pp. 97-100. 
213. Sibunka, J. D.; Pacheco, A. L. Biological and fisheries data on northern puffer, Sphoeroides maculatus (Bloch and Schneider). National Marine Fisheries Service Technical Series Report No. 26, Highlands, New Jersey, 1981.

214. CDC (Centers for Disease Control and Prevention). Neurologic illness associated with eating Florida puffer-fish. Morbid. Mort. Weekly Rep. 2002, 51, 321-323.

215. Quilliam, M.; Wechsler, D.; Marcus, S.; Ruck, B.; Wekell, M.; Hawryluk, T. Detection and identification of paralytic shellfish poisoning toxins in Florida pufferfish responsible for incidents of neurologic illness. In Harmful Algae 2002. Proceedings of the Xth International Conference on Harmful Algae; Steidinger, K. A., Landsberg, J. H., Tomas, C. R., Vargo, G. A., Eds; Florida Fish and Wildlife Conservation Commission and Intergovernmental Oceanographic Commission of UNESCO, 2004; pp. 116-118.

216. Etheridge, S.; Deeds, J.; Hall, S.; White, K.; Flewelling, L.; Abbott, J.; Landsberg, J.; Conrad, S.; Bodager, D.; Jackow, G. Detection methods and their limitations: PSP toxins in Florida puffer fish responsible for human poisoning events in 2004. African J. Mar. Sci. 2006, 28, 383387.

217. Abbott, J.; Landsberg, J.H.; Flewelling, L.J.; Baird, L.; Fisk, S. Transfer of saxitoxins within the Indian River Lagoon, Florida food web. In Proc. Second Symposium on Harmful Algae in the U.S., 9-13 December, 2003; Woods Hole Oceanographic Institution: Woods Hole, MA, 2003; pp. 1-2. Available online: http://www.whoi.edu/redtide/2ndsymposium/SEGoMx_abstracts.pdf [accessed 3 March 2008].

218. Deeds, J. R.; White, K. D.; Etheridge, S. M.; Landsberg, J. H. Concentrations of saxitoxin and tetrodotoxin in three species of puffer fish from the Indian River Lagoon, Florida, USA - the location for multiple cases of saxitoxin puffer fish poisoning from 2002-2004. Trans. Am. Fish. Soc. (in press).

Samples Availability: Available from the authors.

(C) 2008 by the author(s); licensee Molecular Diversity Preservation International, Basel, Switzerland.This article is an open-access article distributed under the terms and conditions of the Creative Commons Attribution license (http://creativecommons.org/licenses/by/3.0/). 